\title{
Bacterial and fungal communities, fermentation, and aerobic stability of conventional hybrids and brown midrib hybrids ensiled at low moisture with or without a homo- and heterofermentative inoculant
}

\author{
J. J. Romero, ${ }^{*}$ Y. Joo,† J. Park,‡ F. Tiezzi,‡ E. Gutierrez-Rodriguez,§ and M. S. Castillo\# ${ }^{1}$ \\ *Animal and Veterinary Sciences, School of Food and Agriculture, University of Maine, Orono 04465 \\ †Department of Animal Science (BK21Plus, Institute of Agriculture and Life Science), Gyeongsang National University, Jinju 52828, \\ Republic of Korea \\ ‡Department of Animal Science, \\ $\S$ Department of Food, Bioprocessing, and Nutrition Sciences, and \\ \#Department of Crop and Soil Sciences, North Carolina State University, Raleigh 27695
}

\section{ABSTRACT}

We evaluated the effects of adding a combination inoculant to 4 corn (Zea mays L.) hybrids harvested at low moisture on the nutritive value, fermentation profile, aerobic stability, bacterial and fungal populations, and community structure. The treatment design was the factorial combination of 4 corn hybrids ensiled with (INO) and without (CON) inoculant. The hybrids were TMF2R737 (MCN), F2F817 (MBR), P2089YHR (PCN), and PI144XR (PBR), ensiled at 44.0, 38.1, 42.0, and $41.3 \%$ of dry matter, respectively; MBR and PBR were brown midrib mutants. The inoculant contained Lactobacillus buchneri and Pediococcus pentosaceus $(4 \times$ $10^{5}$ and $1 \times 10^{5} \mathrm{cfu} / \mathrm{g}$ of fresh corn). The experimental design was a complete randomized design with treatments replicated 6 times. Corn was chopped, treated or not with inoculant, packed into 7.6-L bucket silos, and stored for $100 \mathrm{~d}$. At d 0, we found higher bacterial observed operational taxonomic units in the brown midrib mutants (MBR and PBR) relative to $\mathrm{MCN}$ and $\mathrm{PCN}$ (654 and 534 vs. 434 and $444 \pm 15.5$, respectively). The bacterial and fungal families with the highest relative abundance (RA) were Enterobacteriaceae (61.4\%) and incertae sedis Tremellales (12.5\%). At silo opening, we observed no effects of INO treatment on dry matter recovery $(\sim 94.3 \pm 1.07 \%)$, but aerobic stability was extended for all INO-treated hybrids ( $\sim 217$ vs. $\sim 34.7$ h), except for MBR $(\sim 49 \pm 38 \mathrm{~h})$, due to a decreased yeast population (3.78 vs. $5.13 \pm 0.440 \mathrm{log} \mathrm{cfu} / \mathrm{g}$ of fresh corn) and increased acetic acid concentration (1.69 vs. $0.51 \pm 0.132 \%)$ compared with the control.

Received August 28, 2017.

Accepted November 28, 2017.

${ }^{1}$ Corresponding author: mscastil@ncsu.edu
Furthermore, INO treatment reduced bacterial (61.2 vs. $276 \pm 8.70$ ) and increased fungal (59.8 vs. $43.6 \pm$ 2.95) observed operational taxonomic units compared with CON. We observed that INO treatment increased the RA of Lactobacillaceae across all hybrids ( 99.1 vs. $\sim 58.9$ ), and to larger extent MBR (98.3 vs. $34.3 \pm$ 5.29), and decreased Enterobacteriaceae (0.614 vs. 23.5 $\pm 2.825 \%$ ) among 4 other bacterial families relative to CON. For fungi, INO treatment increased the RA of Debaryomycetaceae $(63.1$ vs. $17.3 \pm 8.55)$ and 5 other fungal families and decreased the RA of Pichiaceae ( 6.47 vs. $47.3 \pm 10.95)$ and incertae sedis Saccharomycetales (8.47 vs. $25.9 \pm 5.748$ ) compared with CON. The bacterial and fungal community structures changed, due to ensiling, to a distinct and more stable community dominated by Lactobacillaceae and Debaryomycetaceae, respectively, when INO treatment was applied relative to CON. In conclusion, the INO treatment used in this study improved low-moisture whole-crop corn silage quality because of a shift in the bacterial and fungal community composition during ensiling.

Key words: silage, inoculant, hybrid, next-generation sequencing

\section{INTRODUCTION}

The increased frequency of extreme weather events (Rosenzweig et al., 2001) poses challenges for adequate silage production. Adverse weather conditions can affect field productivity of corn (Zea mays L.) and limit timely harvest and storage (Rosenzweig et al., 2001; Kung et al., 2015), resulting in corn plants ensiled outside the recommended range of 32 to $35 \%$ of DM concentration (Allen et al., 2003). Harvesting below the recommended range of moisture concentration (i.e., dry corn silage) can result in a cascade of negative events that prevent adequate silage preservation due to highly porous silos, lower packing density, and ultimately 
lower DM digestibility of whole-crop corn (Allen et al., 2003). High-porosity silos are more susceptible to spoilage by aerobic microorganisms (Huber and Soejono, 1976; Muck and Kung, 2007), which triggers excessive heating and an undesirable fermentation profile (Huber and Soejono, 1976; Muck and Kung, 2007), ultimately reducing voluntary intake and milk productivity of dairy cattle (Huber and Soejono, 1976).

The microbial community of corn silages produced in suboptimal conditions (i.e., outside the recommended DM concentration) have not been studied in as much detail compared with optimally stored silages (Muck, 2013). Recurrent extreme weather events combined with delayed harvesting pose challenges for consistent high-quality silage production. Consequently, expanding our understanding of silage microbial communities under suboptimal conditions is critical to help in the development of strategies to ensure successful silage production.

Novel culture-independent techniques, such as nextgeneration sequencing (NGS), can help improve our understanding of silage microbial communities. The NGS techniques have been recently used to describe bacterial communities in fresh and ensiled whole-crop corn (Ni et al., 2017) and commercial bunker wholecrop corn silos (Kraut-Cohen et al., 2016). Nevertheless, to the best of our knowledge, an evaluation of silage bacterial and fungal microbiome using NGS to study the effects of bacterial inoculation across different hybrids of fresh and ensiled whole-crop corn has not yet been performed. The objective of the present study was to evaluate the effect of combo inoculant (homolactic and heterolactic bacteria) applied to several corn hybrids harvested at low moisture on the nutritive value, fermentation profile, aerobic stability, bacterial and fungal populations, taxonomic profile, diversity, and community structure. We hypothesized that adding a combo silage inoculant improves nutritive value, preservation, and aerobic stability to different extents by causing a hybrid-dependent shift in the composition and structure of the bacterial and fungal communities compared with untreated control corn silage.

\section{MATERIALS AND METHODS}

\section{Experimental Site, Design, and Treatments}

The experimental site was located at the Piedmont Research Station in Salisbury, North Carolina (35 $41^{\prime}$ $\left.\mathrm{N} ; 80^{\circ} 37^{\prime} \mathrm{W}\right)$. Corn was planted in a clean-tilled seedbed on April 24, 2014, at a rate of 83,980 live seeds/ha. Based on initial soil test results, fertilization followed the recommendations for corn production in North
Carolina (Hardy et al., 2014). Treatments were the factorial combination of 4 corn hybrids and 2 inoculations. The 4 corn hybrids were planted in a complete randomized design with plots replicated 6 times. Corn hybrids were TMF2R737 (MCN; Mycogen Seeds, Indianapolis, IN), P2089YHR (PCN; Pioneer Hi-Bred International, Johnston, IA), F2F817 (MBR; Mycogen Seeds), and P1449XR (PBR; Pioneer Hi-Bred International). Hybrids MBR and PBR were brown mid-rib (BMR) mutants (loci 3 and 1 mutants, respectively). All corn plants were harvested on August 25, 2014, when DM concentration was above $38 \%$ for all hybrids. Corn was clipped to 18-cm stubble height and chopped to 1.9$\mathrm{cm}$ theoretical length using a John Deere 3950 forage harvester equipped with a kernel-processor $(2.5 \mathrm{~mm}$ roll clearance; John Deere, Moline, IL). Two replicated piles (4.3 kg each, fresh basis) were obtained from each corn plot (total of 48 piles). The DM yield was 16.8, $18.7,17.0$, and $20.2 \mathrm{Mg} / \mathrm{ha}( \pm 2.67 \mathrm{SD})$ for $\mathrm{MCN}, \mathrm{PCN}$, $\mathrm{MBR}$, and $\mathrm{PBR}$, respectively.

The 2 silage additives (ADV) evaluated were sterile double-distilled water (control; CON) and inoculant (INO; Biotal Buchneri 500, Lallemand Animal Nutrition, Milwaukee, WI). Each ADV treatment (CON or INO) was applied randomly to 1 of the 2 replicated piles at a rate of $1 \mathrm{~mL} / \mathrm{kg}$ of fresh corn. Inoculation resulted in theoretical final application rates of $\log 5.6 \mathrm{cfu} / \mathrm{g}$ of fresh corn (FW) for Lactobacillus buchneri ATCC number 40788 and $\log 5 \mathrm{cfu} / \mathrm{g}$ of $\mathrm{FW}$ for Pediococcus pentosaceus plus fibrolytic enzymes from Trichoderma reesei $(1,103,3,145$, and $50 \mathrm{mg}$ of sugar released/min per gram for $\beta$-glucanase, xylanase, and galactomannanase activities, respectively; FCC, 2015). Chopped whole-crop corn (3.5 $\mathrm{kg}$ on a fresh basis) was packed into 7.6-L plastic buckets using an A-frame 12-ton hand press and sealed with a rubber gasket lid and duct tape $\left(\sim 192 \pm 11.4 \mathrm{~kg}\right.$ of $\left.\mathrm{DM} / \mathrm{m}^{3}\right)$. Silos were stored at $23^{\circ} \mathrm{C}$ $\left( \pm 1^{\circ} \mathrm{C}\right)$ for $100 \mathrm{~d}$, and weights were recorded individually at d 0 and 100 to determine DM recovery (Arriola et al., 2011).

\section{Sampling Procedure}

At d 0 and 100, samples (250 g on a fresh basis) were taken from each individual replicate to determine nutritive value, fermentation profile, and the bacterial and fungal population via standard plating techniques. In the case of $d 0$, samples were obtained immediately after treatment application. Additional sample subsets were collected at d 0 and 100 to determine the composition and structure of the bacterial and fungal communities using NGS (100 g on a fresh basis) and aerobic stability analysis at d 100 (2.5 kg on a fresh basis). 


\section{Laboratory Analysis}

Nutritional Analysis. From samples taken at d 0 and 100 , subsamples were processed for determination of DM concentration by drying at $60^{\circ} \mathrm{C}$ until constant weight in a forced-air oven. Dried samples were ground to pass the 1-mm screen of a Wiley mill (A. H. Thomas, Philadelphia, PA). Ground samples were further dried to $105^{\circ} \mathrm{C}$ for $16 \mathrm{~h}$ to determine absolute $\mathrm{DM}$ concentration and placed at $600^{\circ} \mathrm{C}$ for $8 \mathrm{~h}$ in a muffle furnace to determine ash concentration (Galicia et al., 2008). Concentrations of NDF (Van Soest et al., 1991) and ADF (AOAC International, 2000; method 973.18) were measured sequentially using an Ankom 200 fiber analyzer (Ankom Technologies, Macedon, NY). Heatstable $\alpha$-amylase was used in the NDF assay with no sodium sulfite, and the results were expressed inclusive of residual ash. Corn $\mathrm{N}$ concentration was determined using the total Kjeldahl digestion procedure (McKenzie and Wallace, 1954). Digested samples were analyzed with a Seal AQ2 discrete auto analyzer (Seal Analytical Inc., Mequon, WI) using U.S. Environmental Protection Agency (1993) method 353.2. Crude protein was calculated by multiplying $\mathrm{N}$ concentration by 6.25 .

Water extracts were prepared by mixing $25 \mathrm{~g}$ of fresh or ensiled corn with $225 \mathrm{~mL}$ of $0.1 \%$ sterile peptone water in a 400C Stomacher blender for 3 min (Seward Ltd., Worthing, UK). The solution was filtered through 2 layers of sterilized cheesecloth, and the $\mathrm{pH}$ of the fluid was measured with a SevenCompact $\mathrm{pH}$ meter fitted with an Inlab Expert Pro ISM pH electrode with an integrated temperature sensor (Mettler-Toledo LLC, Columbus, $\mathrm{OH}$ ). A portion of the extract was acidified to $\mathrm{pH} 2$ with $50 \% \mathrm{H}_{2} \mathrm{SO}_{4}$ and frozen $\left(-30^{\circ} \mathrm{C}\right)$ for further analysis. Thawed samples were centrifuged at $8,000 \times$ $g$ for $20 \mathrm{~min}$ at $4^{\circ} \mathrm{C}$, and the supernatant was analyzed for lactic, acetic, butyric, and propionic acids and 1,2-propanediol and ethanol concentrations (Siegfried et al., 1984) using a Waters high-performance liquid chromatograph system (Waters Co., Milford, MA) fitted with a Rezex RHM ion exchange column (Phenomenex, Torrance, CA) and a Waters 2414 refractive index detector. Ammonia $\mathrm{N}$ concentration $\left(\mathrm{NH}_{3}-\mathrm{N}\right)$ was measured using an adaptation of the Noel and Hambleton (1976) procedure that involved colorimetric N quantification with a Seal AQ2 discrete auto analyzer (Seal Analytical Inc., Mequon, WI). Water-soluble carbohydrate (WSC) concentration was measured using the protocol by DuBois et al. (1956) using sucrose as the standard as described by Hall (2000).

Lactic Acid Bacteria, Yeast and Mold Counts, and Aerobic Stability. An aliquot was taken immediately after filtering with sterilized cheesecloth and used for enumeration of bacterial and fungal populations. Serial (10-fold) dilutions of the water extracts were done in $0.1 \%$ sterile peptone water and pour-plated in de Man, Rogosa and Sharpe agar (CM361, Oxoid Ltd., Waltham, MA) for lactic acid bacteria (LAB) and in Petrifilm yeast and mold count plates (3M Microbiology Products, St. Paul, MN). Plates were incubated for $48 \mathrm{~h}$ at $32^{\circ} \mathrm{C}$ for $\mathrm{LAB}$ and for 72 to $120 \mathrm{~h}$ at $25^{\circ} \mathrm{C}$ for yeast and molds.

Aerobic stability was measured by putting $2.5 \mathrm{~kg}$ of silage in an open plastic bucket $(24.1 \mathrm{~cm}$ height $\times 24.8 \mathrm{~cm}$ diameter) following the procedure described by Arriola et al. (2015). Temperature sensors (HOBO temperature data logger $64 \mathrm{k}$, Onset Computer Co., Bourne, MA) were placed at the center of the biomass, and data were recorded every $30 \mathrm{~min}$ for $29 \mathrm{~d}$. Two additional sensors were placed in the temperature-controlled room $(22.3$ $\pm 0.23^{\circ} \mathrm{C}$ ) to record ambient temperature. Silages were covered with 2 layers of sterile cheesecloth to prevent drying. Aerobic stability was expressed as the amount of time before silage and ambient temperatures differed by more than $2^{\circ} \mathrm{C}$.

Microbial and DNA Extraction. Corn samples $(100 \mathrm{~g}$, fresh basis) were weighed into $15.2 \mathrm{~cm} \times 22.9$ $\mathrm{cm}$ sterile 0.076-mm filter bags (Filtra-Bag, VWR Co., Radnor, PA). Each bag received $200 \mathrm{~mL}$ of a previously sonicated (30 min) and sterile $10 \mathrm{mM}$ potassium PBS at pH 7 containing Tween 20 at $0.05 \%$ (GutiérrezRodríguez et al., 2012). Bags containing samples were hand-massaged 6 times and sonicated for $30 \mathrm{~min}$ in an 8800 M Series Ultrasonic cleaning bath (Branson, Danbury, CT). After sonication, the supernatant was centrifuged at $18,500 \times g$ for $10 \mathrm{~min}$ at $4^{\circ} \mathrm{C}$ until pellets were formed. The supernatant was discarded and the pellets were kept at $-80^{\circ} \mathrm{C}$ awaiting DNA extraction. Extraction of DNA was done using the PowerLyzerPowerSoil DNA isolation kit (MO Bio Labs Inc., Carlsbad, CA) following the manufacturer-recommended procedure. Resulting DNA was quantified using a NanoPhotometer Pearl (Denville Scientific, Holliston, MA) and visualized by $2 \%$ agarose gel electrophoresis. The concentration of DNA for each PCR reaction was standardized for all samples at $5 \mathrm{ng} / \mu \mathrm{L}$.

NGS. Extracted DNA from pellets was analyzed using the Illumina (San Diego, CA) MiSeq platform for pair-end reads and 500 sequencing cycles. Amplification of the V4 hypervariable region of the $16 \mathrm{~S}$ rRNA was achieved using the primer pair F515 (5'-GTGCCAGCMGCCGCGGTAA-3') and R806 (5'-GGACTACHVGGGTWTCTAAT-3') and the internal transcribed spacer (ITS)- 1 region of fungi BITS (5'-ACCTGCGGARGGATCA-3') and B58S3 (5'-GAGATCCRTTGYTRAAAGTT-3') as described by Caporaso et al. 
(2011) and by Bokulich and Mills (2013). Amplification of the targeted region was achieved with the following reaction chemistry: $5 \mu \mathrm{L}$ of Gotaq Green master mix (Promega, Madison, WI), $11.9 \mu \mathrm{L}$ of DNase-free water, $0.5 \mu \mathrm{L}$ of $\mathrm{MgCl}_{2}(50 \mathrm{mM}), 0.5 \mu \mathrm{L}$ of deoxynucleotide triphosphates $(10 \mathrm{mM}), 1 \mu \mathrm{L}$ of DNA forward and reverse primers $(10 \mu M)$, and $5 \mu \mathrm{L}$ of DNA template adjusted for all samples to an average final concentration of $1 \mathrm{ng} / \mu \mathrm{L}$ of reaction total volume. Reaction conditions for bacterial $16 \mathrm{~S}$ amplification were as follows: an initial $95^{\circ} \mathrm{C}$ for $3 \mathrm{~min}$; followed by 35 cycles of $95^{\circ} \mathrm{C}$ for $45 \mathrm{~s}, 50^{\circ} \mathrm{C}$ for $60 \mathrm{~s}$, and $72^{\circ} \mathrm{C}$ for $90 \mathrm{~s}$; and a final extension of $72^{\circ} \mathrm{C}$ for $10 \mathrm{~min}$. Reaction conditions for fungal ITS-1 amplification were as follows: $95^{\circ} \mathrm{C}$ for 3 min, followed by 35 cycles of $95^{\circ} \mathrm{C}$ for $30 \mathrm{~s}, 55^{\circ} \mathrm{C}$ for 45 $\mathrm{s}$, and $72^{\circ} \mathrm{C}$ for $60 \mathrm{~s}$, and a final extension of $72^{\circ} \mathrm{C}$ for $10 \mathrm{~min}$. Amplicons were mixed at roughly equivalent ratios based on electrophoretic band intensity and purified using GE Illustra MicroSpin S-300 HR columns (GE Healthcare Biosciences, Piscataway, NJ). Pooled samples were submitted to the University of California Davis Genome Center for library preparation using the kappa paired-end kit, cluster generation, and 250-bp paired-end sequencing (500 cycles) on the MiSeq platform.

Sequencing Analysis. Raw Illumina fastq files were demultiplexed, quality filtered (Q30), and analyzed using QIIME 1.9.1 and the GreenGenes 13.8, UNITE fungal ITS reference database. Bacterial 16S amplicon analysis (250-bp reads) was truncated at any site of more than 3 sequential bases receiving a quality score $<1 \mathrm{E}-5$, and any read containing ambiguous base calls or barcode or primer errors were discarded. QIIME was used to assign operational taxonomic units (OTU) using UCLUST, with a threshold of $97 \%$ pairwise identity. The OTU were classified taxonomically using a similar procedure described by Bokulich et al. (2012) using a 0.80 confidence threshold for taxonomic assignment. Jackknifed principal coordinates were computed from these estimates to compress dimensionality into 3 -dimensional principal coordinate analysis plots. The $\beta$-diversity (between-samples community dissimilarity) was calculated in QIIME using the weighted UniFrac distances for $16 \mathrm{~S}$ and the Bray-Curtis distances for ITS-1 (Lozupone and Knight, 2005). The $\alpha$-diversity was also estimated from rarefied OTU tables to assess sampling depth coverage (Lozupone and Knight, 2005; Cole et al., 2007, 2009; Caporaso et al., 2011).

\section{Statistical Analyses}

Data were analyzed separately for d 0 and 100 as a completely randomized design replicated 6 times. The model used to analyze the data was

$$
\mathrm{Y}_{\mathrm{ijk}}=\mu+\mathrm{T}_{\mathrm{i}}+\mathrm{C}_{\mathrm{j}}+\mathrm{TC}_{\mathrm{ij}}+\mathrm{E}_{\mathrm{ijk}},
$$

where $Y_{i j k}=$ the response from the kth experimental unit receiving the ith level of hybrid and the jth level of ADV $; \mu=$ general mean, $T_{i}=$ effect of hybrid $i, C_{j}=$ effect of $\mathrm{ADV} \mathrm{j}, \mathrm{TC}_{\mathrm{ij}}=$ effect of the hybrid $\mathrm{i} \times \mathrm{ADV} \mathrm{j}$ interaction, and $\mathrm{E}_{\mathrm{ijk}}=$ experimental error.

We used the GLM procedure of SAS version 9.4 (SAS Institute Inc., Cary, NC) for data analysis. When a 2 -factor interaction effect was present, we used the SLICE option to analyze the simple effects. Microbial data were converted to $\log _{10}$ to conduct statistical analysis and are presented on a fresh basis. ShapiroWilk test revealed that data were normally distributed. Mean separation was based on the PDIFF procedure of LSMEANS. Treatments were considered different when $P \leq 0.05$.

Further analysis was conducted to understand the overall relationships among the microbiota profile and silage quality variables measured at d 100 for CON and INO. The data set was first split into CON and INO. Both silage quality variables and microbiota RA were adjusted by the effect of hybrid using a linear model. Residuals were considered as adjusted measures and were used in the association analysis. To account for the nonlinearity of the relationship between silage quality and microbiota RA, each bacterial and fungal family RA was classified into 3 categories: low, medium, and high RA. Categories were allocated based on the 34 th and 67 th percentiles of the specific family RA. A linear model was used to test the effect of family RA categories on silage quality variables, and pairwise contrasts between the 3 categories were used to identify trends in the change of silage quality variables as a function of family RA. This analysis was performed in R utilizing the packages "car" (Fox and Weisberg, 2011) and "lsmeans" (Lenth et al., 2016), which uses Tukey adjustment for multiple testing.

\section{RESULTS AND DISCUSSION}

\section{Before Ensiling (0 d)}

Nutritional Composition. We found a hybrid effect $(P<0.001)$ and no ADV effect $(P \geq 0.21)$ for all nutrient composition responses (Table 1). The DM concentration at ensiling ranged from 38.1\% (hybrid MBR) to $44.0 \%$ (hybrid MCN). Risk of silage spoilage increases when DM concentration is higher than 35, 40, and $40 \%$ for bunker, concrete stave, and bag silos, respectively (Weiss, 2003). At high DM concentrations, compacting the silos to optimal densities (>224 kg/ $\mathrm{m}^{3}$; Ruppel, 1992) becomes challenging and will result in silages with high porosity and increased susceptibil- 
ity to spoilage by aerobic microorganisms (Huber and Soejono, 1976; Muck and Kung, 2007).

Concentration of OM was not different among hybrids except for MBR, which was slightly lower than the rest (96.8 vs. $\sim 97.5 \pm 0.15 \%$ of DM; $P<0.05$ ). The OM values coincide with several reports in the literature ranging from 96.2 to $97.2 \%$ of OM and 38.3 to $41.3 \%$ of DM (Thomas et al., 2001; Huisden et al., 2009; Queiroz et al., 2012). We found higher CP, WSC, and $\mathrm{NH}_{3}-\mathrm{N}$ values in $\mathrm{MBR}$ relative to the other hybrids $(P<0.05$; Table 1$)$.

Concentration of NDF was not different and was greatest for MCN and MBR compared with PCN and PBR (45.5 and $44.7 \%$ of DM vs. 41.8 and $42.3 \pm 0.94 \%$ of DM; $P<0.05$; Table 1). We observed a similar pattern for ADF concentration, but only MCN had higher values compared with both PBR and PCN (22.7 vs. $20.5 \%$ of $\mathrm{DM}$ and $19.9 \pm 0.70 \%$ of DM; $P<0.05$ ), whereas MBR was higher than PCN only (21.8 vs. 19.9; $P<0.05$; Table 1). We found lower $\mathrm{pH}$ for PCN than for MCN and MBR (5.60 vs. 5.81 and $5.77 \pm 0.071 ; P$ $<0.05)$ but $\mathrm{pH}$ was not different from PBR (5.70; Table $1)$. Most differences before ensiling were attributed to MBR, probably due to its lower maturity (38.1\% of DM, 3/4 kernel milk line) compared with the other hybrids ( $\sim 42.4 \%$ of DM, black layer) and genotypic differences among hybrids. Nutritional composition values for the hybrids used in our study were within similar ranges reported for hybrids with percentage of DM concentrations between 39.3 and 41\% (Der Bedrosian et al., 2012; Queiroz et al., 2012).

Background Microbial Population. We did not find treatment effects on the initial population of yeast and molds among corn hybrids $(P>0.08$ for both hybrid and ADV). Nevertheless, we found higher LAB counts in both BMR mutants (MBR and PBR) compared with MCN and PCN hybrids (Table 1). The background LAB population was high enough $(>6.73$ $\pm 0.129 \mathrm{log} \mathrm{cfu} / \mathrm{g}$ of fresh corn) to provide an adequate LAB concentration for spontaneous fermentation during ensiling (Pahlow et al., 2003). Schmidt and Kung (2010) and Comino et al. (2014) reported comparable LAB counts for corn hybrids with similar DM concentration (40.0 and $43.9 \%$, respectively). Few studies have compared microbial population counts before ensiling between BMR and conventional hybrids, and none have compared microbial population counts between isogenic hybrids (i.e., only differing in the BMR mutation). Consequently, the effect of the specific BMR mutation may be confounded with other genetic differences. Contreras-Govea et al. (2011) showed a lower epiphytic LAB count for a BMR loci 3 corn hybrid compared with a conventional corn hybrid (6.18 vs. $7.35 \mathrm{log} \mathrm{cfu} / \mathrm{g}$ of FW, respectively), but the DM concentration was lower ( 35.2 vs. $39.2 \%$, respectively).

All rarefaction curves approached the saturation plateau, indicating that the coverage of bacterial (Supplemental Figure S1; https://doi.org/10.3168/jds.2017

Table 1. Nutritional composition and microbial counts of chopped whole-crop corn as a function of hybrid type (HYB) and silage additives $(\mathrm{ADV})$ at $\mathrm{d} 0^{1,2}$

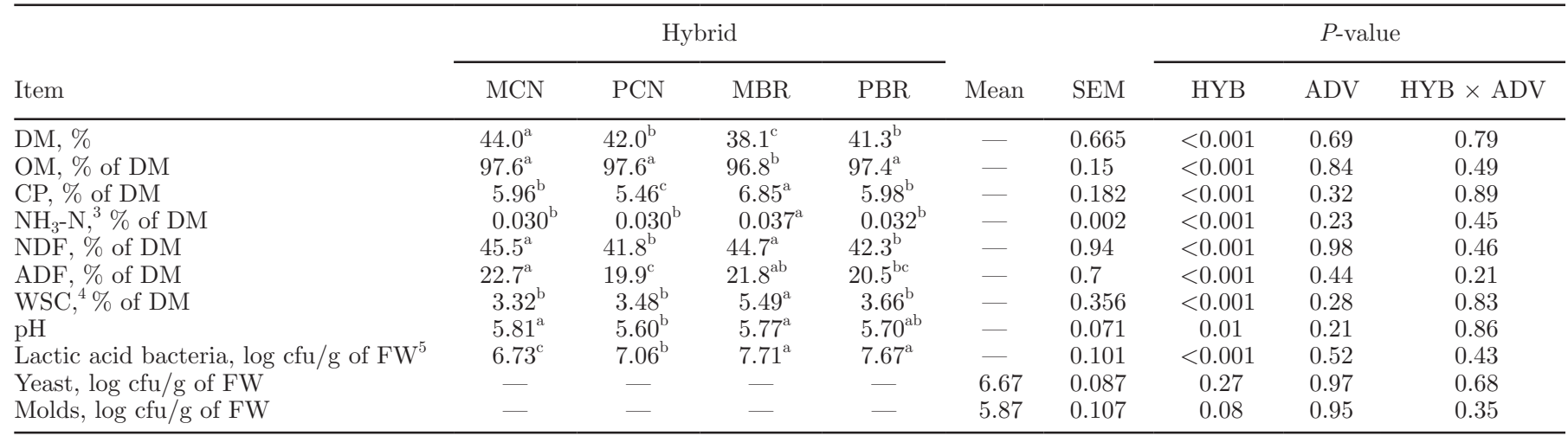

\footnotetext{
${ }^{\mathrm{a}-\mathrm{c}}$ Means with different superscripts within a row are significantly different $(P \leq 0.05)$.

${ }^{1} \mathrm{MCN}, \mathrm{PCN}, \mathrm{MBR}$, and PBR corn hybrids are TMF2R737, P2089YHR, F2F817, and P1449XR, respectively. Hybrids MCN and MBR are property of Mycogen Seeds (Indianapolis, IN), and hybrids PCN and PBR are property of Pioneer Hi-Bred International (Johnston, IA); MBR and PBR are brown midrib hybrids.

${ }^{2}$ Additives were control (water) and inoculant (Biotal Buchneri 500; Lallemand Animal Nutrition, Milwaukee, WI) delivering Lactobacillus buchneri 40788 and Pediococcus pentosaceus at 400,000 and 100,000 cfu/g of fresh corn, respectively.

${ }^{3} \mathrm{NH}_{3}-\mathrm{N}=$ ammonia $\mathrm{N}$.

${ }^{4} \mathrm{WSC}=$ water-soluble carbohydrates.

${ }^{5} \mathrm{FW}=$ fresh corn.
} 
-13754) and fungal (Supplemental Figure S2; https:// doi.org/10.3168/jds.2017-13754) diversity was sufficient to evaluate the bacterial and fungal community composition of whole-crop corn at d 0 . At a sequencing depth of 16,000 and 5,000 sequences per sample for bacteria and fungi, respectively, we did not find an INO effect on bacterial and fungal observed OTU $(P>$ $0.20)$, Simpson's evenness index $(P>0.47)$, and bacterial phylogenetic diversity $(P>0.92)$. We found greater bacterial observed OTU and phylogenetic diversity $(P$ $<0.001$ ) for both MBR versus the other hybrids (654 vs. $\sim 471$ and 30.5 vs. $\sim 22.3$, respectively) and PBR versus conventional hybrids (534 vs. $\sim 439 \pm 15.5$ and 24.8 vs. $\sim 21.0 \pm 0.62)$ at $\mathrm{d} 0(P<0.05)$. These results suggest that there could have been higher bacterial diversity in the BMR compared with the conventional hybrids tested in this study. However, the causes and consequences of this increased diversity remain unclear. Also, we observed a slightly more uneven fungal community in MCN versus PCN and PBR (0.022 vs. 0.032 and $0.038 \pm 0.0033 ; P<0.05)$, as indicated by the Simpson's evenness index $(P<0.007)$. The majority of $16 \mathrm{~S}$ sequences belonged to phyla Proteobacteria, Bacteroidetes, and Actinobacteria, each one representing 84.0, 7.1 , and $4.5 \%$ of total sequences on average, respectively. Using NGS, McGarvey et al. (2013) reported that Proteobacteria and Firmicutes were the most abundant phyla, accounting for 89.6 and $8.1 \%$ of total sequences, respectively, in $10 \%$ bloom alfalfa wilted for $5.5 \mathrm{~h}$ to a final DM of $35 \%$. Romero et al. (2017b) reported that Firmicutes and Proteobacteria represented 83.6 and
$16.2 \%$ of total sequences, respectively, in oats at the heading stage wilted for $21 \mathrm{~h}$ to a final DM of $45 \%$.

We did not observe INO effects $(P>0.05)$ on the 203 bacterial families detected at d 0. Enterobacteriaceae was the most abundant (61.4\%), followed by Sphingobacteriaceae (6.1\%), and lower than 5\% RA for Xanthomonadaceae, Brucellaceae, Rhizobiaceae, Microbacteriaceae, Pseudomonadaceae, Alcaligenaceae, and Sphingomonadaceae (Table 2). Effects of hybrid occurred for Rhizobiaceae, Alcaligenaceae, and Sphingomonadaceae; nevertheless, all differences were below the $5 \%$ RA level. An interaction effect of hybrid $\times$ ADV was found for Pseudomonadaceae $(P=0.04$; Table 2$)$ because INO-treated MBR had a lower RA compared with untreated MBR (2.88 vs. $3.78 \pm 0.257 \%$; $P<$ $0.05)$. However, it is unclear how INO could have affected Pseudomonadaceae RA for fresh MBR. The most abundant genera were unidentified, Cronobacter, and Erwinia for Enterobacteriaceae; Sphingobacterium for Sphingobacteriaceae; and Ochrobactrum for Brucellaceae. Ni et al. (2017) also reported the presence of sequences belonging to Erwinia, Sphingobacterium, and Ochrobactrum genera in fresh whole-plant corn using NGS. Cronobacter spp. are emerging opportunistic human pathogens mostly found in plant sources (Sani and Odeyemi, 2015). Conversely, members of the genus Erwinia are mostly plant pathogens and plant-associated bacteria (Kado, 2006). Romero et al. (2017b) reported the presence of Erwinia and Cronobacter sequences in wilted oats at very low RA ( 0.84 and $0.48 \%)$ compared with the $23.5 \%$ reported by McGarvey et al. (2013) for

Table 2. Relative abundance (\%) of bacterial families identified from 16S ribosomal DNA sequences extracted from chopped whole-crop corn as a function of hybrid (HYB) and silage additives (ADV) at $\mathrm{d} 0^{1,2}$

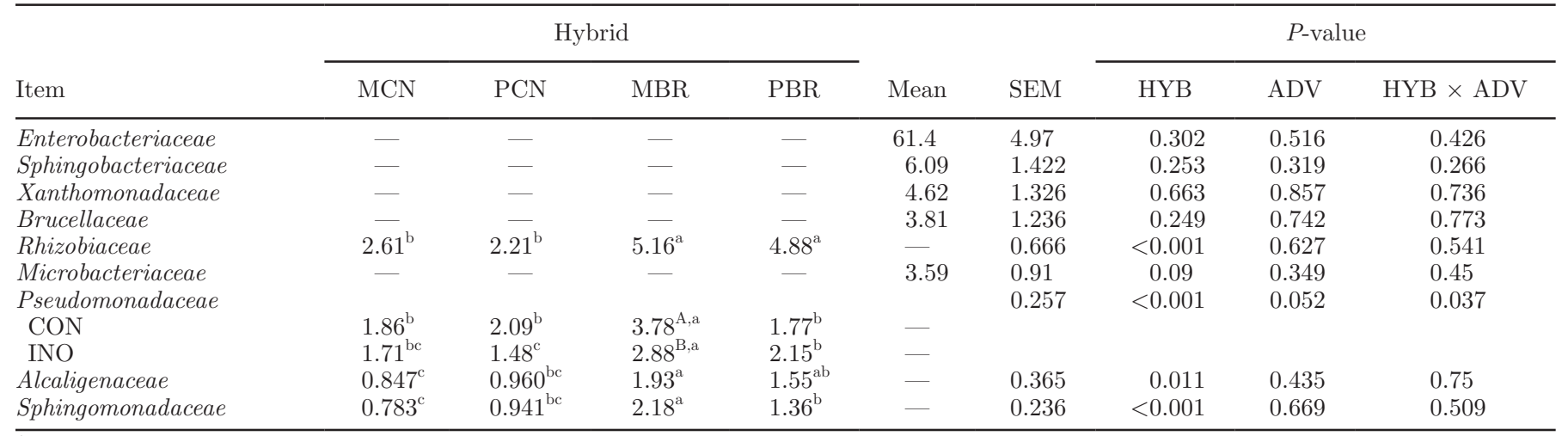

\footnotetext{
$\overline{\mathrm{A}, \mathrm{B}}$ Means with different uppercase superscripts within a column are significantly different $(P \leq 0.05)$.

${ }^{\mathrm{a}-\mathrm{c}}$ Means with different lowercase superscripts within a row are significantly different $(P \leq 0.05)$.

${ }^{1} \mathrm{MCN}, \mathrm{PCN}, \mathrm{MBR}$, and PBR corn hybrids are TMF2R737, P2089YHR, F2F817, and P1449XR, respectively. Hybrids MCN and MBR are property of Mycogen Seeds (Indianapolis, IN), and hybrids PCN and PBR are property of Pioneer Hi-Bred International (Johnston, IA); MBR and PBR are brown midrib hybrids.

${ }^{2} \mathrm{CON}=$ control (water); INO = inoculant (Biotal Buchneri 500; Lallemand Animal Nutrition, Milwaukee, WI) delivering Lactobacillus buchneri 40788 and Pediococcus pentosaceus at 400,000 and 100,000 cfu/g of fresh corn, respectively.
} 
Table 3. Relative abundance (\%) of fungal families identified from internal transcribed spacer 1 (ITS-1) region sequences extracted from chopped whole-crop corn as a function of hybrid (HYB) and silage additives (ADV) at d $0^{1,2}$

\begin{tabular}{|c|c|c|c|c|c|c|c|c|c|}
\hline \multirow[b]{2}{*}{ Item } & \multicolumn{4}{|c|}{ Hybrid } & \multirow[b]{2}{*}{ Mean } & \multirow[b]{2}{*}{ SEM } & \multicolumn{3}{|c|}{$P$-value } \\
\hline & $\mathrm{MCN}$ & $\mathrm{PCN}$ & MBR & PBR & & & HYB & $\mathrm{ADV}$ & $\mathrm{HYB} \times \mathrm{ADV}$ \\
\hline Incertae sedis Tremellales & $7.00^{\mathrm{b}}$ & $21.4^{\mathrm{a}}$ & $9.15^{\mathrm{b}}$ & $12.5^{\mathrm{b}}$ & - & 4.269 & 0.003 & 0.884 & 0.087 \\
\hline Unidentified Ascomycota & $7.59^{\mathrm{b}}$ & $6.03^{\mathrm{b}}$ & $17.9^{\mathrm{a}}$ & $13.5^{\mathrm{a}}$ & - & 3.273 & 0.001 & 0.151 & 0.673 \\
\hline Debaryomycetaceae & $3.27^{\mathrm{b}}$ & $12.4^{\mathrm{a}}$ & $12.4^{\mathrm{a}}$ & $17.2^{\mathrm{a}}$ & - & 3.194 & $<0.001$ & 0.319 & 0.97 \\
\hline Unidentified Pleosporales & $9.84^{\mathrm{a}}$ & $6.51^{\mathrm{b}}$ & $11.0^{\mathrm{a}}$ & $8.91^{\mathrm{ab}}$ & - & 1.626 & 0.025 & 0.815 & 0.587 \\
\hline Unidentified Dothideomycetes & $1.58^{\mathrm{a}}$ & $1.30^{\mathrm{ab}}$ & $0.837^{\mathrm{b}}$ & $0.994^{\mathrm{b}}$ & - & 0.287 & 0.035 & 0.709 & 0.721 \\
\hline Trichomacea & - & - & - & - & 0.726 & 0.4984 & 0.442 & 0.481 & 0.54 \\
\hline Unidentified Basidiomycota & $0.171^{\mathrm{b}}$ & $1.08^{\mathrm{a}}$ & $0.276^{\mathrm{b}}$ & $0.428^{\mathrm{b}}$ & - & 0.1829 & $<0.001$ & 0.966 & 0.39 \\
\hline Incertae sedis Sporidiobolales & $0.344^{\mathrm{c}}$ & $0.583^{\mathrm{a}}$ & $0.468^{\mathrm{b}}$ & $0.357^{\mathrm{c}}$ & - & 0.0554 & $<0.001$ & 0.157 & 0.618 \\
\hline Mucoraceae & - & - & - & - & 0.26875 & 0.0903 & 0.918 & 0.727 & 0.515 \\
\hline
\end{tabular}

${ }^{\mathrm{a}-c}$ Means with different lowercase superscripts within a row are significantly different $(P \leq 0.05)$.

${ }^{1} \mathrm{MCN}, \mathrm{PCN}, \mathrm{MBR}$, and PBR corn hybrids are TMF2R737, P2089YHR, F2F817, and P1449XR, respectively. Hybrids MCN and MBR are property of Mycogen Seeds (Indianapolis, IN), and hybrids PCN and PBR are property of Pioneer Hi-Bred International (Johnston, IA); MBR and PBR are brown midrib hybrids.

${ }^{2}$ Additives were control (water) and inoculant (Biotal Buchneri 500; Lallemand Animal Nutrition, Milwaukee, WI) delivering Lactobacillus buchneri 40788 and Pediococcus pentosaceus at 400,000 and 100,000 cfu/g of fresh corn, respectively.

Erwinia in fresh alfalfa, a legume. Erwinia herbicola has been previously reported in fresh Italian ryegrass (Lolium multiflorum; Heron et al., 1993).

The predominant ITS-detected sequence belonged to the Ascomycota phyla at $41.2 \%$ and was followed by lower Basidiomycota (14.2\%) and Zygomycota (0.3\%) phyla. We did not observe INO effects $(P>0.05)$ on the 109 fungal families detected at d 0 (Table 3). Incertae sedis Tremellales was the most abundant (12.5\%), followed by unidentified Ascomycota and Debaryomycetaceae (both at $\sim 11.3 \%$ ) and unidentified Pleosporales (9.1\%); Mycosphaerellaceae, Nectriaceae, unidentified Dothideomycetes, Trichomacea, unidentified Basidiomycota, incertae sedis Sporidiobolales, and Mucoraceae were lower than $3 \%$ (Table 3). Nevertheless, the majority of remaining fungal sequences $(\sim 45.0 \% \mathrm{RA})$ were unidentified. Table 3 shows that the BMR in this study had differences in RA at d $0(P<0.04)$ compared with MCN for unidentified fungi ( $\sim 38.7$ vs. $58.5 \pm 6.46 \%$, respectively), Debaryomycetaceae ( $\sim 14.8$ vs. $3.27 \pm$ 3.194, respectively), and unidentified Dothideomycetes ( $\sim 0.92$ vs. $1.58 \pm 0.287$, respectively); compared with PCN for incertae sedis Tremellales ( 10.8 vs. $21.4 \pm$ 4.27 , respectively); and compared with both conventional hybrids for unidentified Ascomycota ( $\sim 15.7$ vs. $\sim 6.81 \pm 3.273$, respectively). The most abundant genera were Meyerozyma for Debaryomycetaceae; Hannaella, Bullera, and Bulleromyces for incertae sedis Tremellales; Cercospora for Mycosphaerellaceae; and Gibberella and Fusarium for Nectriaceae. Meyerozyma spp. are yeasts found in natural ecosystems, including soils and fruits, and can have strong antifungal activity against molds in the phyllosphere (Corte et al., 2015). Hannaella spp., Bullera spp., and Bulleromyces spp. also occur frequently on plant leaf surfaces and are considered important phyllosphere-inhabiting yeasts (Nakase, 2000; Landell et al., 2014). Cercospora spp., Gibberella spp., and Fusarium spp. are molds that are among the most relevant and damaging plant pathogens (Goodwin et al., 2001; Desjardins, 2003). Gibberella spp. are teleomorphs of Fusarium spp., both producing a wide array of potent toxins that affect the health of animals and humans (Desjardins, 2003).

\section{Silo Opening (100 d)}

Nutritional Composition. With the exception of NDF $(P=0.08)$, we found hybrid effects on all other nutritive value estimates $(P<0.001$; Table 4$)$. All hybrids were different among each other in terms of DM concentration and ranked similarly to $\mathrm{d} 0$, with MCN having the highest DM concentration, followed by lower PCN, PBR, and MBR $(42.7,40.3,38.9$, and $36.1 \pm 0.68 \%$, respectively; $P<0.05)$. There were minor differences in OM concentration due to hybrid $(P$ $<0.05)$. Lowest OM was for MBR (96.8), followed by $\mathrm{PBR}, \mathrm{MCN}$, and $\mathrm{PCN}(97.1,97.5$, and $97.7 \pm 0.03 \%$ of DM, respectively; $P<0.05$ ). Thomas et al. (2001) reported OM of 96.1, Huisden et al. (2009) reported OM of 97.0, and Queiroz et al. (2012) reported OM of $95.9 \%$ of DM for ensiled corn hybrids with DM values of $39.2,39.9$, and $40.6 \%$, respectively. Both conven- 
Table 4. Nutritional composition of chopped whole-crop corn as a function of hybrid (HYB) and silage additives (ADV) at d $100^{1,2}$

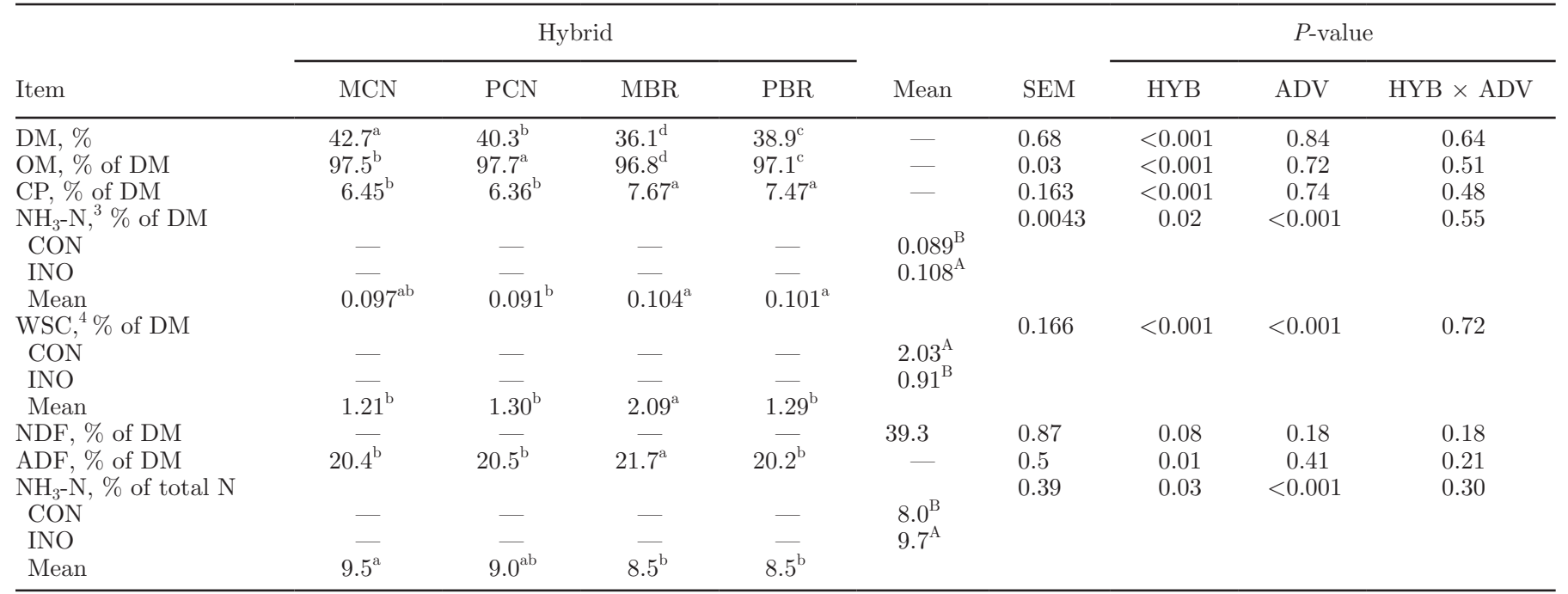

${ }_{\mathrm{A}, \mathrm{B}}$ Means with different uppercase superscripts within a column are significantly different $(P \leq 0.05)$.

${ }^{\mathrm{a}-\mathrm{d}}$ Means with different lowercase superscripts within a row are significantly different $(P \leq 0.05)$.

${ }^{1} \mathrm{MCN}, \mathrm{PCN}, \mathrm{MBR}$, and PBR corn hybrids are TMF2R737, P2089YHR, F2F817, and P1449XR, respectively. Hybrids MCN and MBR are property of Mycogen Seeds (Indianapolis, IN), and hybrids PCN and PBR are property of Pioneer Hi-Bred International (Johnston, IA); MBR and PBR are brown midrib hybrids.

${ }^{2} \mathrm{CON}=$ control (water); INO = inoculant (Biotal Buchneri 500; Lallemand Animal Nutrition, Milwaukee, WI) delivering Lactobacillus buchneri 40788 and Pediococcus pentosaceus at 400,000 and 100,000 cfu/g of fresh corn, respectively.

${ }^{3} \mathrm{NH}_{3}-\mathrm{N}=$ ammonia $\mathrm{N}$.

${ }^{4} \mathrm{WSC}=$ water-soluble carbohydrates.

tional hybrids had lower CP concentrations compared with BMR hybrids ( $\sim 6.41$ vs. $\sim 7.57 \pm 0.163 \%$ of $\mathrm{DM}$, respectively; $P<0.05$ ), and $\mathrm{PCN}$ had a lower concentration of $\mathrm{NH}_{3}-\mathrm{N}$ compared with BMR silages (0.091 vs. $0.103 \pm 0.0043 \%$, respectively; $P<0.05)$. However, $\mathrm{NH}_{3}-\mathrm{N}$ expressed as a percentage of total $\mathrm{N}$ was higher in MCN than in BMR silages (9.5 vs. $\sim 8.5 \pm 0.39$, respectively; $P<0.05$ ). Der Bedrosian et al. (2012) reported in nonisogenic BMR and conventional corn hybrids ensiled at $41 \%$ of DM for $90 \mathrm{~d}$ less CP $(6.8$ vs. $9.0 \%$ of $\mathrm{DM}$ ) and a higher $\mathrm{NH}_{3}-\mathrm{N}(13.8$ vs. $7.6 \%$ of $\mathrm{N})$, respectively. Both WSC and ADF were higher $(P<0.05)$ in MBR compared with the other hybrids ( 2.09 vs. $\sim 1.27 \pm 0.166$ and 21.7 vs. $20.9 \pm 0.50 \%$ of $\mathrm{DM}$, respectively). Overall, negligible differences were observed in the nutritional composition of the ensiled hybrids evaluated, mostly relegated to MBR versus the conventional hybrids. As previously discussed, MBR had a lower maturity compared with the other hybrids.

We found ADV effects $(P<0.001)$ on $\mathrm{NH}_{3}-\mathrm{N}$ and WSC concentrations. Inoculation resulted in silages with slightly greater $\mathrm{NH}_{3}-\mathrm{N}$ concentration $(P<0.05)$ compared with $\mathrm{CON}$ when expressed as percentage of DM (0.108 vs. $0.089 \pm 0.0043)$ and percentage of total $\mathrm{N}(9.7$ vs. $8.0 \pm 0.39)$. In agreement with our results, $\mathrm{Hu}$ et al. (2009) reported that when L. buchneri was applied at the same rate used in this study to wholeplant corn with $39.1 \%$ of $\mathrm{DM}, \mathrm{NH}_{3}-\mathrm{N}$ levels increased compared with control $(0.26 \%$ of DM vs. $0.16 \%$ of $\mathrm{DM})$. However, there were no differences when the DM was $32.7 \%$ ( $\sim 0.13 \%$ of DM.). Kleinschmit and Kung (2006a) reported no differences in $\mathrm{NH}_{3} \mathrm{~N}$ when the same inoculant was applied to $36.1 \%$ of DM corn silage ensiled for $70 \mathrm{~d}(\sim 0.106 \%$ of DM, respectively), but in that experiment the $\mathrm{pH}$ was unaffected by inoculation $(\sim 3.73)$ compared with the minor $\mathrm{pH}$ decrease observed in this study (4.02 vs. $3.80 \pm 0.041$ for INO and CON, respectively; $P<0.05$; Table 5). As suggested by Driehuis et al. (2001) and $\mathrm{Hu}$ et al. (2009), the increased presence of $\mathrm{NH}_{3}-\mathrm{N}$ in silages treated with $L$. buchneri seems to be associated with an increased final $\mathrm{pH}$ in treated silages, although this relationship is inconsistent (Kleinschmit and Kung, 2006b). Conversely, lower concentrations of $\mathrm{NH}_{3}-\mathrm{N}$ are more related to silages that undergo a more homolactic fermentation ( $\mathrm{Hu}$ et al., 2009).

Residual WSC was lower for INO versus CON silages (0.91 vs. $2.03 \pm 0.166 ; P<0.05)$. Similarly, Schmidt and Kung (2010) and Reich and Kung (2010) reported a reduction in WSC when the same inoculant was applied to whole-plant corn (34.3 and $30.8 \%$ of DM, respectively) and compared with the control (0.76 vs. 
Table 5. Fermentation measures of chopped whole corn as a function of hybrid (HYB) and silage additives (ADV) at d $100^{1,2}$

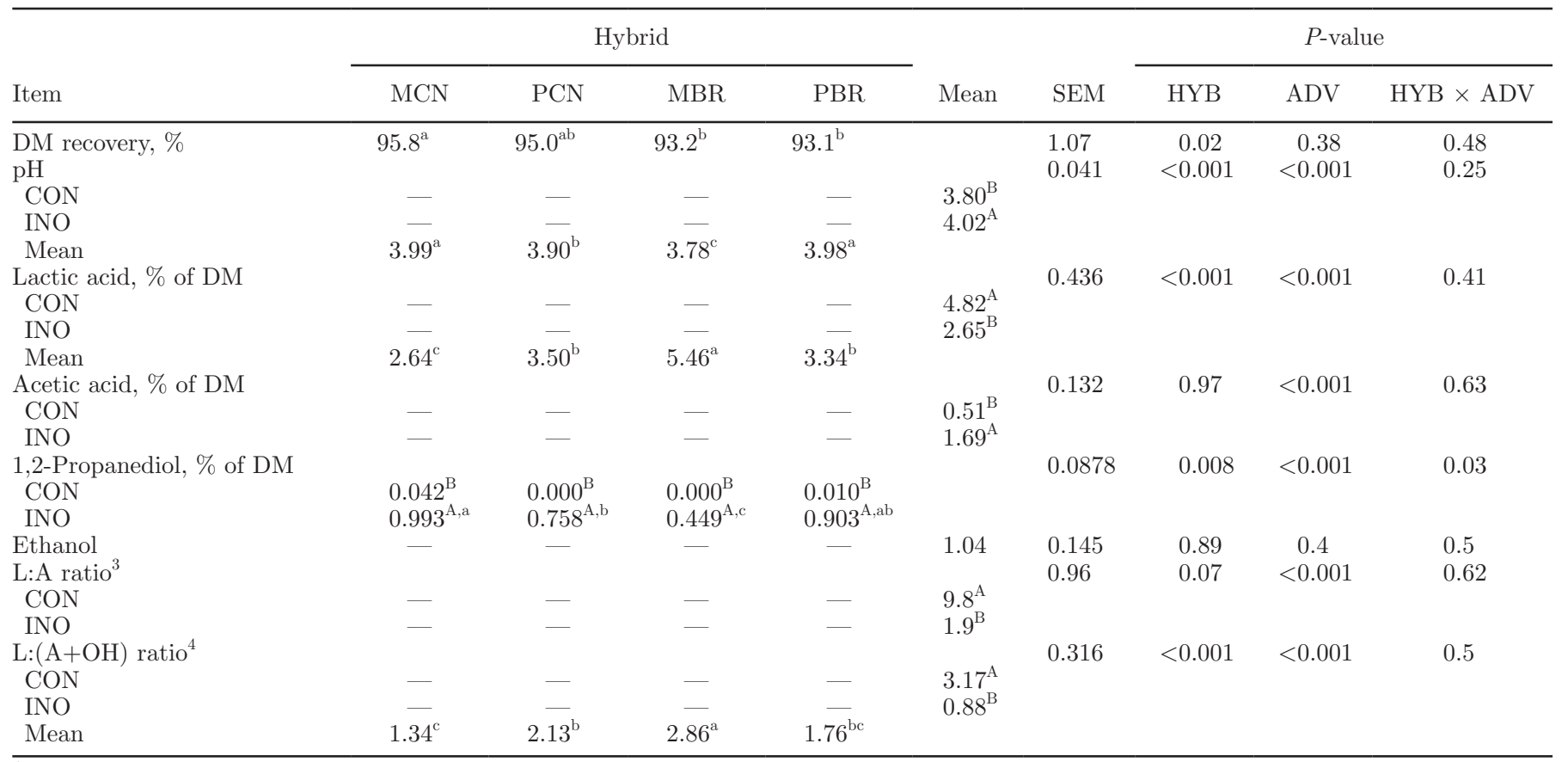

$\overline{\mathrm{A}, \mathrm{B}}$ Means with different uppercase superscripts within a column are significantly different $(P \leq 0.05)$.

${ }^{\mathrm{a}-\mathrm{C}}$ Means with different lowercase superscripts within a row are significantly different $(P \leq 0.05)$.

${ }^{1} \mathrm{MCN}, \mathrm{PCN}, \mathrm{MBR}$, and PBR corn hybrids are TMF2R737, P2089YHR, F2F817, and P1449XR, respectively. Hybrids MCN and MBR are property of Mycogen Seeds (Indianapolis, IN), and hybrids PCN and PBR are property of Pioneer Hi-Bred International (Johnston, IA); MBR and PBR are brown midrib hybrids.

${ }^{2} \mathrm{CON}=$ control (water); INO = inoculant (Biotal Buchneri 500; Lallemand Animal Nutrition, Milwaukee, WI) delivering Lactobacillus buchneri 40788 and Pediococcus pentosaceus at 400,000 and 100,000 cfu/g of fresh corn, respectively.

${ }^{3} \mathrm{~L}=$ lactic acid; $\mathrm{A}=$ acetic acid.

${ }^{4} \mathrm{~L}=$ lactic acid; $\mathrm{A}=$ acetic acid; $\mathrm{OH}=$ ethanol plus 1,2-propanediol.

$1.09 \%$ of DM and 2.0 vs. $3.3 \%$ of DM, respectively). Although not significant, a numerical decrease in WSC was observed in the meta-analysis study conducted by Kleinschmit and Kung (2006b) when L. buchneri was applied at rates higher than $5 \mathrm{log}$ cfu/g of corn $(1.32 \%$ of DM vs. $1.55 \%$ of $\mathrm{DM}$ ), with a significant reduction of WSC being detected in the case of small-grain silages. Reich and Kung (2010) suggested that the lower residual WSC was most likely a consequence of a more extensive fermentation in inoculated silages compared with the control.

Fermentation Measures. We observed hybrid effects for all fermentation measures $(P<0.02)$ except for acetic acid, ethanol, and the lactic acid to acetic acid (L:A) ratio $(P>0.07$; Table 5$)$. The DM recovery was lower for both BMR $(\sim 93.1 \%)$ compared with MCN ( 98.5\%), and it was intermediate for PCN (95.0\% being similar to MCN and to the 2 BMR). We hypothesize that the higher initial DM concentration at d 0 for MCN hybrid (44.0\%) compared with the BMR $(\sim 39.7 \%)$ explains the differences observed in
DM recovery at d 100, as opposed to BMR being more susceptible to DM losses during ensiling. McDonald et al. (1991) indicated an indirect inverse relationship between DM concentration of silages and fermentation losses. Few studies have published DM recovery comparisons between BMR and conventional corn hybrids. Mustafa et al. (2005) observed no differences between a BMR and a conventional corn hybrid (97.9 vs. $98.4 \%$, respectively) ensiled at similar DM (38.1 and 39.0\%, respectively), though lines were not isogenic. We observed minor differences for $\mathrm{pH}$ ranging from 3.78 to 3.99 (Table 5). Overall, we found adequate corn silage acidification because the $\mathrm{pH}$ was below 4.2 (Cherney and Cherney, 2003). The MBR (lowest pH) had the highest concentration of lactic acid (5.46), followed by PCN and PBR (3.50 and 3.34, respectively), which were higher than MCN $(2.64 \pm 0.436 ; P<0.05)$. No differences were observed between hybrids for acetic acid $(\sim 1.10 \pm 0.132 ; P=0.97)$ and ethanol concentration $(\sim 1.04 \pm 0.145 ; P=0.89)$. Fermentation increases with higher moisture levels (MBR had the lowest DM \%) 
due to an increased microbial activity, especially of the homolactic bacteria relative to the heterolactic types (Beck, 1978; McDonald et al., 1991). Der Bedrosian et al. (2012) reported no differences in $\mathrm{pH}$ (3.72 vs. 3.79), lactic acid (4.5\% of DM vs. $6.0 \%$ of $\mathrm{DM})$, and acetic acid $(0.9 \%$ of $\mathrm{DM}$ vs. $1.0 \%$ of $\mathrm{DM})$ between a BMR and a conventional corn hybrid ensiled at $41 \%$ of DM for 90 d; however, they reported higher ethanol concentration in the conventional hybrid compared with the BMR (3.9\% of DM vs. $1.2 \%$ of DM, respectively). We did not observe hybrid effects for L:A ratio $(\sim 5.85 \pm 0.96$; $P=0.07)$. However, the lactic acid to acetic acid plus ethanol and 1,2-propanediol $[\mathrm{L}:(\mathrm{A}+\mathrm{OH})]$ ratio was the highest in MBR (2.86), followed by PCN (2.13), which had a ratio similar to PBR (1.76) but higher than MCN $(1.34 \pm 0.316 ; P<0.05)$.

There was an effect of ADV on all fermentation measures $(P<0.001)$ except DM recovery and ethanol concentration $(P>0.40$; Table 5$)$. The application of INO did not affect DM recovery $(\sim 94.3 \pm 1.07 \% ; P=$ 0.38 ) and coincides with previous reports in the literature for corn hybrids treated with the same inoculant used in this study and with percentage of DM recovery ranging from 88.1 to $96.4 \%$ and initial DM concentrations between 28.2 and $38.2 \%$ of DM (Reich and Kung, 2010; Schmidt and Kung, 2010; Queiroz et al., 2013). Despite using an inoculant containing L. buchneri, no reductions were observed in DM recovery like reported in the meta-analysis study of Kleinschmit and Kung (2006b; 94.5 vs. $95.5 \%$ for treated and untreated silages, respectively), most likely due to the presence of $P$. pentosaceus in the inoculant, which reduces the negative effects of heterolactic fermentation on DM recovery during fermentation (Driehuis et al., 2001; Reich and Kung, 2010). We found slightly higher $\mathrm{pH}$ in INO compared with CON (4.02 vs. $3.80 \pm 0.041$, respectively; $P<0.05$ ), most likely due to the ability of $L$. buchneri to metabolize lactic acid into acetic acid and 1,2-propanediol (Oude Elferink et al., 2001). This was reflected in lower lactic acid (2.65 vs. $4.82 \pm 0.436 \%$ of $\mathrm{DM})$ and higher acetic acid (1.69 vs. $0.51 \pm 0.132 \%$ of $\mathrm{DM}$ ) and 1,2-propanediol (0.776 vs. $0.013 \pm 0.0878 \%$ of DM) in INO versus CON, respectively $(P<0.05)$, at silo opening. Similarly, Kleinschmit and Kung (2006b) reported an increase in $\mathrm{pH}$ (3.88 vs. 3.7) and acetic acid (3.89\% of DM vs. $2.18 \%$ of DM) and a decrease in lactic acid concentration ( $4.79 \%$ of DM vs. $6.59 \%$ of DM) when more than $5 \mathrm{log} \mathrm{cfu} / \mathrm{g}$ of $\mathrm{FW}$ of L. buchneri was applied to whole-corn plants $(\mathrm{DM}=30.7 \%)$ compared with untreated silage. Ethanol concentration was unaffected by INO application $(\sim 1.04 \%$ of DM; $P=0.40)$ in agreement with Kleinschmit and Kung (2006b), who reported no differences with the addition of $L$. buch- neri compared with untreated silage $(1.47 \%$ of DM vs. $1.62 \%$ of DM, respectively).

We found an interaction effect of hybrid $\times$ ADV on 1,2-propanediol ( $P=0.03$; Table 5). Inoculant application resulted in an increased concentration of 1,2-propanediol compared with CON but to different extents depending on hybrid. Within INO treatments, MCN had a concentration that was higher compared with PCN and MBR but similar to PBR. The smallest increase was observed for MBR (0.449), with PCN (0.758) being similar to PBR (0.903) but lower than MCN $(0.993 \pm 0.0878 \%$ of DM; $P<0.05)$. The production of 1,2-propanediol confirms successful growth of L. buchneri as 1,2-propanediol is produced along with acetic acid and traces amount of ethanol from lactic acid degradation when silage $\mathrm{pH}$ reaches a value lower than 5.8 during the later stages of fermentation $(>56$ d of ensiling; Oude Elferink et al., 2001; Kleinschmit and Kung, 2006a). The fact that the lowest concentration of 1,2-propanediol in INO was observed for MBR correlates with the numerical reduction observed for acetic acid concentration relative to the other INOtreated hybrids. The 1,2-propanediol does not share the antifungal properties of acetic acid, but it can be converted to propionic acid (strong antifungal) in the presence of Lactobacillus diolivorans (Krooneman et al., 2002). However, propionic and butyric acids were not detectable in this study for any treatment $(<0.014 \%$ of $\mathrm{DM})$. Both the $\mathrm{L}: \mathrm{A}(1.9$ vs. $9.8 \pm 0.96)$ and $\mathrm{L}:(\mathrm{A}+\mathrm{OH})$ $(0.88$ vs. $3.17 \pm 0.316)$ ratios seem to confirm a more dominant heterofermentative lactate fermentation typical of $L$. buchneri -treated silages for INO versus CON, respectively $(P<0.05)$. Similarly, Huisden et al. (2009) and Queiroz et al. (2013) reported a decrease in the L:A ratios when the same inoculant was applied to corn silage ensiled at $39.1 \% \mathrm{DM}$ and $28.2 \% \mathrm{DM}$ when compared with a control (0.91 vs. 3.63 and 1.66 vs. 2.18), respectively.

Microbial Population and Aerobic Stability. We found no hybrid effects on LAB $(\sim 6.43 \pm 0.21 \mathrm{log}$ $\mathrm{cfu} / \mathrm{g}$ of FW), yeast $(\sim 4.45 \pm 0.440 \log \mathrm{cfu} / \mathrm{g}$ of FW), and mold $(\sim 0.42 \pm 0.492 \mathrm{log} \mathrm{cfu} / \mathrm{g}$ of $\mathrm{FW})$ populations at silo opening $(P>0.17$; Table 6$)$. Schmidt and Kung (2010) observed no differences in LAB ( 7.01) and yeast counts $(\sim 2.85)$ but lower mold counts $(2.30$ vs. 3.83) between a BMR and conventional 120-d corn silage with 32.4 and $38.2 \%$ DM, respectively. Addition of INO slightly increased LAB (6.59 vs. $6.26 \pm 0.21 \log$ $\mathrm{cfu} / \mathrm{g}$ of FW) and largely decreased yeast populations (3.78 vs. $5.13 \pm 0.44 \mathrm{log} \mathrm{cfu} / \mathrm{g}$ of FW) when compared with CON $(P<0.05)$. We did not find differences in mold counts as a result of INO addition $(\sim 0.42 \pm 0.492$ $\log \mathrm{cfu} / \mathrm{g}$ of FW). Minor or no increases in LAB counts 
Table 6. Microbial counts and aerobic stability of chopped whole corn as a function of hybrid (HYB) and silage additives (ADV) at d $100^{1,2}$

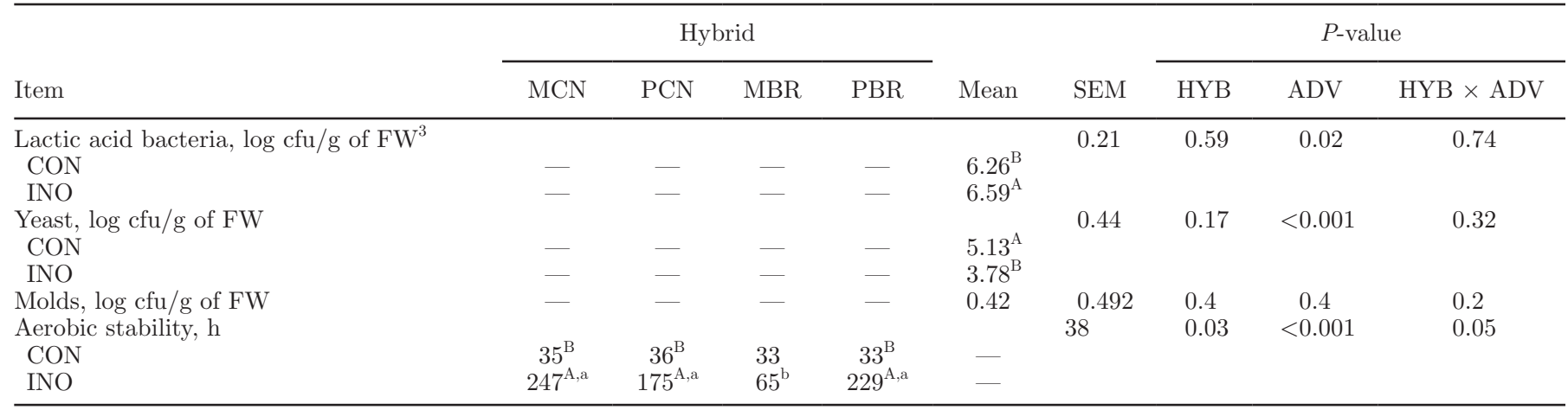

${ }_{\mathrm{A}, \mathrm{B}}$ Means with different uppercase superscripts within a column are significantly different $(P \leq 0.05)$.

${ }^{\mathrm{a}, \mathrm{b}}$ Means with different lowercase superscripts within a row are significantly different $(P \leq 0.05)$.

${ }^{1} \mathrm{MCN}, \mathrm{PCN}, \mathrm{MBR}$, and PBR corn hybrids are TMF2R737, P2089YHR, F2F817, and P1449XR, respectively. Hybrids MCN and MBR are property of Mycogen Seeds (Indianapolis, IN), and hybrids PCN and PBR are property of Pioneer Hi-Bred International (Johnston, IA); MBR and PBR are brown midrib hybrids.

${ }^{2} \mathrm{CON}=$ control (water); INO = inoculant (Biotal Buchneri 500; Lallemand Animal Nutrition, Milwaukee, WI) delivering Lactobacillus buchneri 40788 and Pediococcus pentosaceus at 400,000 and 100,000 cfu/g of fresh corn, respectively.

${ }^{3} \mathrm{FW}=$ fresh corn.

accompanied with changes in fermentation profiles with similar inoculants have been reported in some instances for barley (Hristov and McAllister, 2002; Zahiroddini et al., 2006) and oats silage (Romero et al., 2017b). However, when the same inoculant was applied to corn ensiled under high-moisture conditions, a larger difference was observed versus the control (9.3 vs. $7.1 \mathrm{log}$ cfu/g of FW; Romero et al., 2017a). We believe this is likely the consequence of the low-moisture concentration conditions tested in this trial. The same inoculant used in this study was reported to increase LAB (8.21 vs. 5.72 and 8.78 vs. $5.68 \mathrm{log} \mathrm{cfu} / \mathrm{g}$ of FW) and reduce yeast ( 2.65 vs. 4.39 and 0.67 vs. $4.33 \mathrm{log} \mathrm{cfu} / \mathrm{g}$ of $\mathrm{FW}$ ) populations when compared with noninoculated treatments in corn silage ensiled at $34.3 \%$ DM (Schmidt and Kung, 2010) and 30.8\% DM (Reich and Kung, 2010). However, the mold population was reduced only in Schmidt and Kung (2010; 1.96 vs. $2.92 \mathrm{log} \mathrm{cfu} / \mathrm{g}$ of FW) and not in Reich and Kung (2010; 0.62 log cfu/g of $\mathrm{FW})$. There was an interaction effect of hybrid $x$ ADV on aerobic stability $(P=0.05$; Table 6$)$. Inoculant application resulted in a more aerobically stable silage compared with CON for MCN (247 vs. 35), PCN (175 vs. 36$)$, and PBR (229 vs. $33 \pm 38 \mathrm{~h} ; P<0.05)$ but not for MBR (65 vs. 33 ). For CON, the aerobically stable periods were not different across all hybrids $(\sim 34)$, but when INO was added all hybrids except MBR were not different from each other $(\sim 217$ vs. $65 \pm 38 \mathrm{~h}$, respectively; $P<0.05$ ). All INO hybrids except MBR were aerobically stable for more than $168 \mathrm{~h}$, the minimum recommended for minimizing silage spoilage from silo opening until feeding (Wilkinson and Davies, 2012).
Although acetic acid concentrations were similar across all INO hybrids, a numerical decrease was observed for INO MBR. However, a more plausible explanation of the failure of INO to extend the aerobic stability for MBR is the higher concentration of WSC at silo opening observed in this hybrid compared with the others. Higher residual WSC is nutritionally desirable as it is rapidly digestible in the rumen (Van Amburgh et al., 2015) but also carries a higher risk of yeast spoilage during silo opening if not enough acetate or propionate is present (McDonald et al., 1991). Greater aerobic stability in INO is the result of the increased acetic acid production by L. buchneri found in the inoculant product, which has the potential to reduce spoilage after silo opening by inhibiting undesirable yeast and molds (Driehuis et al., 2001; Kleinschmit and Kung, 2006b). Similar improvements for the same inoculant compared with untreated silage were reported in the meta-analysis of Kleinschmit and Kung (2006b; 503 vs. 25 h). Interestingly, Schmidt and Kung (2010) observed an improvement in aerobic stability (115 vs. $60 \mathrm{~h}$ ) in a BMR with $32.4 \%$ DM but not in a conventional corn ensiled at 38.2 and $33.1 \%$ of DM (69 vs. 42 and 58 vs. $51 \mathrm{~h}$, respectively) when inoculant was compared with a control. However, no differences in acetic acid concentration were observed due to inoculant application for the conventional corns, but a trend was observed for the BMR.

All rarefaction curves approached saturation plateau, indicating that the coverage of bacterial (Supplemental Figure S3; https://doi.org/10.3168/jds.2017-13754) and fungal (Supplemental Figure S4; https://doi.org/10 
$.3168 /$ jds.2017-13754) diversity was sufficient to evaluate the bacterial and fungal community composition of ensiled whole-crop corn at d 100. At a sequencing depth of 16,000 and 5,000 sequences per sample for bacteria and fungi, respectively, we found a hybrid effect for fungal $(P=0.01)$ but not for bacterial $(P=0.17)$ observed OTU and an INO effect for both bacterial and fungal observed OTU at d $100(P<0.001)$. The MCN had more observed fungal OTU compared with the other hybrids (62.5 vs. $48.1 \pm 4.40 ; P<0.05)$, and INO had less bacterial OTU compared with the CON (61.2 vs. $276 \pm 8.70)$ and more fungal OTU compared with the CON (59.8 vs. $43.6 \pm 2.95$, respectively; $P<0.05$ ). In the case of the Simpson's evenness index, we observed only an inoculation effect for fungi, indicating that INO fungal communities were more uneven compared with CON silages ( 0.033 vs. $0.055 \pm 0.0047 ; P<0.05)$. When phylogenetic diversity was evaluated only for bacteria, hybrid and INO effects were observed $(P<0.02)$. The MBR had a higher phylogenetic diversity compared with the other hybrids (12.1 vs. $\sim 10.2 \pm 0.63)$ and INO had a lower phylogenetic diversity compared with the CON (5.57 vs. $15.7 \pm 0.41 ; P<0.05$ ). These results suggest that INO reduces the bacterial and increases fungal diversity and fungal community uneveness consistently across all ensiled hybrids tested in this study. At d 100, a significant shift occurred compared with d 0 , with most $16 \mathrm{~S}$ sequences being part of the Firmicutes and Proteobacteria phyla (86.0 and $14.5 \%$ of total $16 \mathrm{~S}$ sequences, respectively). Each of the Actinobacteria and Bacteroidetes phylum represented only $0.20 \%$ of total sequences. McGarvey et al. (2013) reported also a similar population shift, with Firmicutes and Proteobacteria being the most abundant phyla and accounting for 70.6 and $26.9 \%$ of total sequences, respectively, in alfalfa ensiled for $40 \mathrm{~d}$. Romero et al. (2017b) reported a high RA for Firmicutes (99.8) and low Proteobacteria $(0.07 \%)$ in wilted whole-crop oats ensiled for $217 \mathrm{~d}$.

The weighted UniFrac principal coordinates analysis plot indicated a clear separation and difference in the distribution and structure of the bacterial community at $\mathrm{d} 0$ versus $100(P=0.001 ; \mathrm{R}=0.97)$ and within $\mathrm{d} 100$ between the CON and INO $(P=0.001 ; \mathrm{R}=0.93$; Figure 1 ) according to the analysis of similarities (ANOSIM) test of distance metrics. At d 100, an interaction effect of hybrid $\times \mathrm{ADV}$ was found for Lactobacillaceae $(P=$ 0.015 ; Table 7) because all INO-treated silages had a higher Lactobacillaceae RA compared with CON, but a higher increase was observed for MBR compared with the other hybrids because untreated MBR had a lower RA compared with the other untreated hybrids; for Leuconostocaceae $(P=0.005)$ because untreated MBR had a higher RA compared with the other untreated hybrids and INO decreased Leuconostocaceae RA for all hybrids except PCN when compared with $\mathrm{CON}$; and for Enterococcaceae $(P=0.008)$ because untreated MCN had a higher RA compared with the other untreated hybrids and INO decreased Enterococcaceae RA for all hybrids except PCN when compared with CON. Across all hybrids, addition of INO decreased the RA of Enterobacteriaceae, Streptococcaceae, Xanthomonadaceae, Aeromonadaceae, and Brucellaceae versus CON (Table 7). The most abundant genera were Lactobacillus for Lactobacillaceae, unidentified for Enterobacteriaceae, Leuconostoc and unidentified for Leuconostocaceae, and Lactococcus for Streptococcaceae. The reduction of bacterial diversity in INO silages can be explained by the dominance of Lactobacillaceae (>98\% RA) when INO was applied versus CON ( 53). Ni et al. (2017) reported in $30.5 \%$ DM whole-crop corn ensiled for $60 \mathrm{~d}$ approximately 70, 28, and 3\% RA for Lactobacillaceae, Enterobacteriaceae, and Leuconostocaceae, respectively, and Kraut-Cohen et al. (2016) reported in 37.7\% DM whole-crop corn ensiled for an undisclosed period approximately 40, 12, and 9\% RA for Lactobacillaceae, Corynebacteriaceae, and Enterobacteriaceae, respectively. Romero et al. (2017b) found that adding the same inoculant tested in this study to wilted oats ensiled for 217 d increased Lactobacillaceae (57.4 vs. $3.9 \%$ ) and reduced Leuconostocaceae (42.3 vs. 95.8\%) RA relative to untreated silage. Similarly, Eikmeyer et al. (2013) observed an increase in the RA of the Lactobacillus genus in grass treated with L buchneri $(6$ $\log$ cells/g of fresh grass) after $14 \mathrm{~d}$ (34 vs. 31\%) and more after 58 d (67 vs. $35 \%$ ) of ensiling when compared with untreated silage. As a result, the Lactococcus and to a lesser degree the Leuconostoc and Weisella genera were more abundant in the untreated silages (Eikmeyer et al., 2013). Addition of L. buchneri containing inoculants resulted in silages dominated by the Lactobacillus genus with much less diversity than untreated silages, which can sustain more Enterobacteriaceae and other genera that can potentially include pathogenic species of bacteria. Thus, adding this type of inoculants may have the added benefit of contributing to silage safety.

At d 100, a significant shift occurred compared with d 0, with most ITS region sequences being part of the Ascomycota phylum (88.7\% of total ITS sequences), followed by a minor presence of Basidiomycota and Zygomycota (6.79 and $1.85 \%$, respectively) phyla. Only $2.63 \%$ of ITS sequences remained unidentified at d 100 . Similarly, Romero et al. (2017b) reported the predominance of Ascomycota (97.4\%) relative to Basidiomycota and Zygomycota using NGS in wilted oats ensiled for 217 d. Moreover, May et al. (2001) reported in corn silage that most $18 \mathrm{~S}$ rRNA gene sequences belonged to 

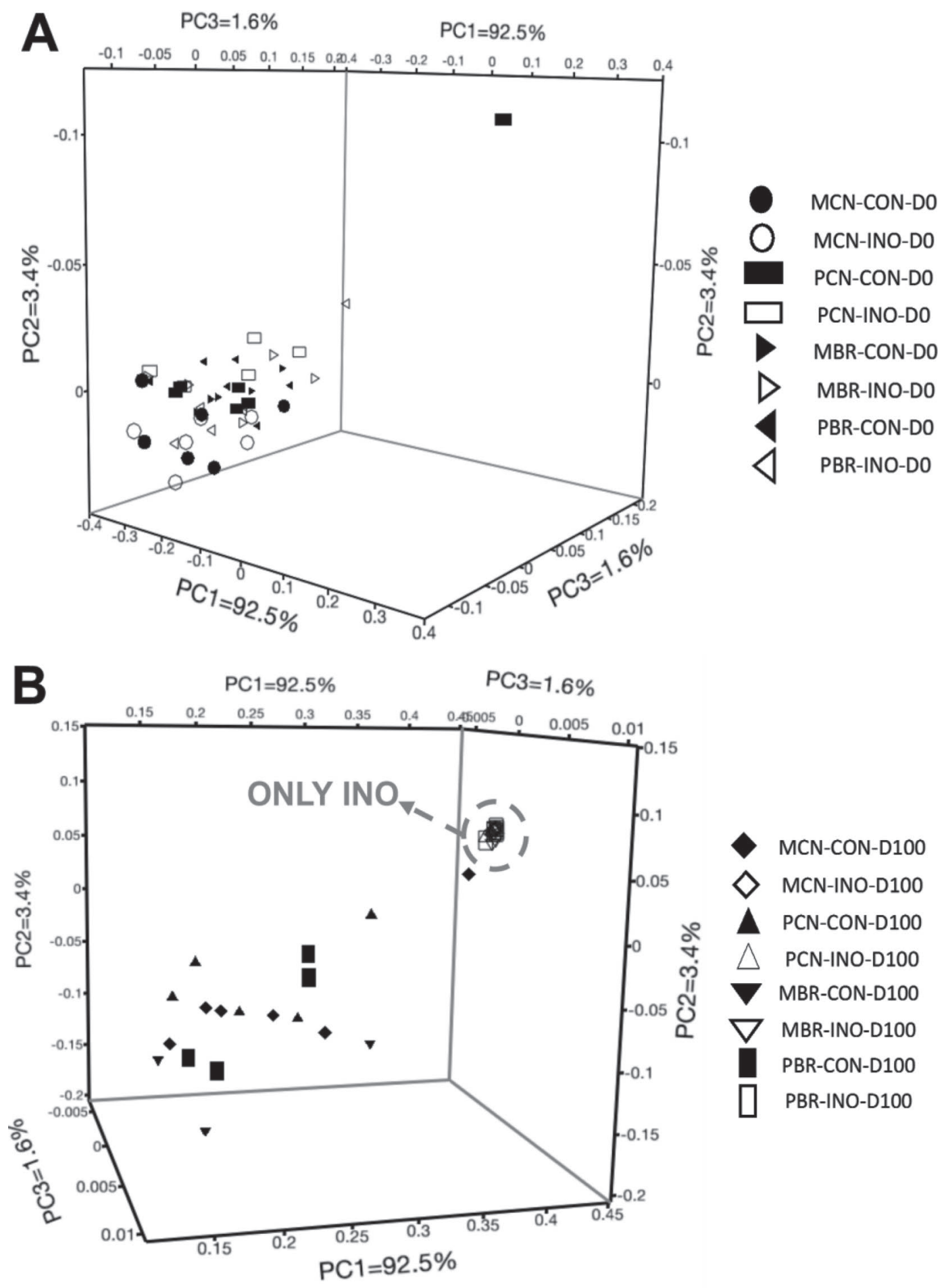

Figure 1. Weighted UniFrac principal coordinate (PC) analysis plots for bacterial operational taxonomic units coming from (A) fresh and (B) ensiled $(100 \mathrm{~d})$ chopped whole-crop corn as a function of hybrid and bacterial inoculation. CON = control (water), INO = inoculant. MCN, PCN, MBR, and PBR corn hybrids are TMF2R737, P2089YHR, F2F817, and P1449XR, respectively. Hybrids MCN and MBR are property of Mycogen Seeds (Indianapolis, IN), and PCN and PBR are property of Pioneer Hi-Bred International (Johnston, IA). MBR and PBR are brown midrib hybrids. The inoculant used was Biotal Buchneri 500 (Lallemand Animal Nutrition, Milwaukee, WI) delivering Lactobacillus buchneri 40788 and Pediococcus pentosaceus at 400,000 and 100,000 cfu/g of fresh corn, respectively. 
Table 7. Relative abundance (\%) of bacterial families identified from $16 \mathrm{~S}$ ribosomal DNA sequences extracted from chopped whole-crop corn as a function of hybrid (HYB) and silage additives (ADV) at $\mathrm{d} 100^{1,2}$

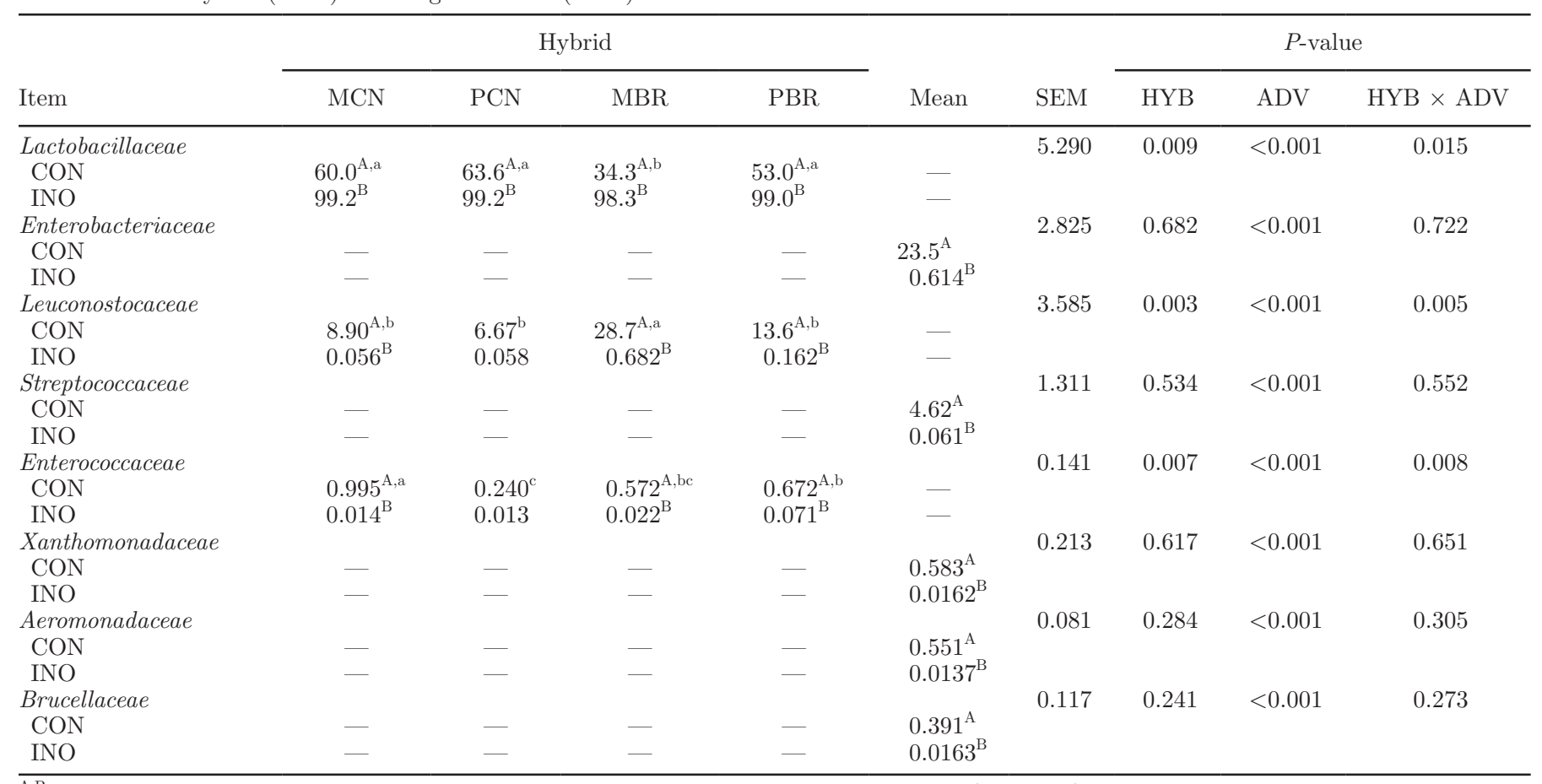

\footnotetext{
${ }_{\mathrm{A}, \mathrm{B}}$ Means with different uppercase superscripts within a column are significantly different $(P \leq 0.05)$.

${ }^{a-c}$ Means with different lowercase superscripts within a row are significantly different $(P \leq 0.05)$.

${ }^{1}$ MCN, PCN, MBR, and PBR corn hybrids are TMF2R737, P2089YHR, F2F817, and P1449XR, respectively. Hybrids MCN and MBR are property of Mycogen Seeds (Indianapolis, IN), and hybrids PCN and PBR are property of Pioneer Hi-Bred International (Johnston, IA); MBR and PBR are brown midrib hybrids.

${ }^{2} \mathrm{CON}=$ control (water); INO = inoculant (Biotal Buchneri 500; Lallemand Animal Nutrition, Milwaukee, WI) delivering Lactobacillus buchneri 40788 and Pediococcus pentosaceus at 400,000 and 100,000 cfu/g of fresh corn, respectively.
}

Ascomycota, followed by Basidiomycota and to a lesser degree Zygomycota using denaturing gradient gel electrophoresis. Using a Bray-Curtis principal coordinates analysis plot we observed a clear separation and difference in the distribution and structure of the fungal community at $\mathrm{d} 0$ and $100(P=0.001 ; \mathrm{R}=0.86)$ and within $\mathrm{d} 100$ between the CON and INO $(P=0.001$; $\mathrm{R}=0.79$; Figure 2) according to the ANOSIM test of distance metrics. Effects of hybrid were observed on incertae sedis Tremellales due to a higher RA for MCN versus the other hybrids (11.5 vs. $\sim 3.73 \pm 3.330 \%$, respectively; $P=0.020$; Table 8 ) and unidentified $A s$ comycota due to a higher RA for MCN versus MBR and PBR (3.70 vs. 1.70 and $1.72 \pm 0.741 \%$, respectively; $P$ $=0.015)$. Across all hybrids, addition of INO increased the RA $(P<0.01)$ of Debaryomycetaceae (63.1 vs. $17.3 \pm 8.55)$, unidentified Ascomycota (4.23 vs. 0.721 \pm 0.741 ), unidentified fungi (3.99 vs. $0.455 \pm 1.985)$, Mucoraceae (2.75 vs. $0.816 \pm 1.120$ ), incertae sedis Sporidiobolales ( 0.742 vs. $0.266 \pm 0.2382$ ), and unidentified Pleosporales ( 0.790 vs. $0.137 \pm 0.2452)$ and decreased the RA of Pichiaceae (6.47 vs. $47.3 \pm 10.95)$ and in- certae sedis Saccharomycetales (8.47 vs. $25.9 \pm 5.748$ ). An interaction effect of hybrid $\times$ ADV was found for Nectriaceae $(P=0.004)$ because INO increased its RA across all hybrids versus $\mathrm{CON}(\sim 2.43$ vs. $\sim 0.25$, respectively) except for MBR $(\sim 0.38)$ and because within INO, PCN and MBR (2.03 and 1.80, respectively) were higher than MBR (0.673) but lower than MCN (3.47 $\pm 0.357 \%)$. An increased fungal diversity was observed in INO silages because the 3 most abundant families represented $90.5 \%$ of the fungal community compared with the $78.0 \%$ observed for CON. This is most likely a consequence of the different susceptibility to the antifungal activity of acetic acid across fungi (Moon, 1983; Cabo et al., 2002). Romero et al. (2017b) found no differences when the same inoculant was applied to wilted oats silage, but a large numerical decrease was observed for Pichiaceae (41.2 vs. 82.5) and an increase was observed for Trichocomaceae (14.0 vs. 1.87) and unidentified Ascomycota (11.3 vs. $0.51 \%$ ) relative to untreated silage. These results seem to indicate that L. buchneri containing inoculants may consistently decrease RA of Pichiaceae and increase unidentified Ascomycota across 

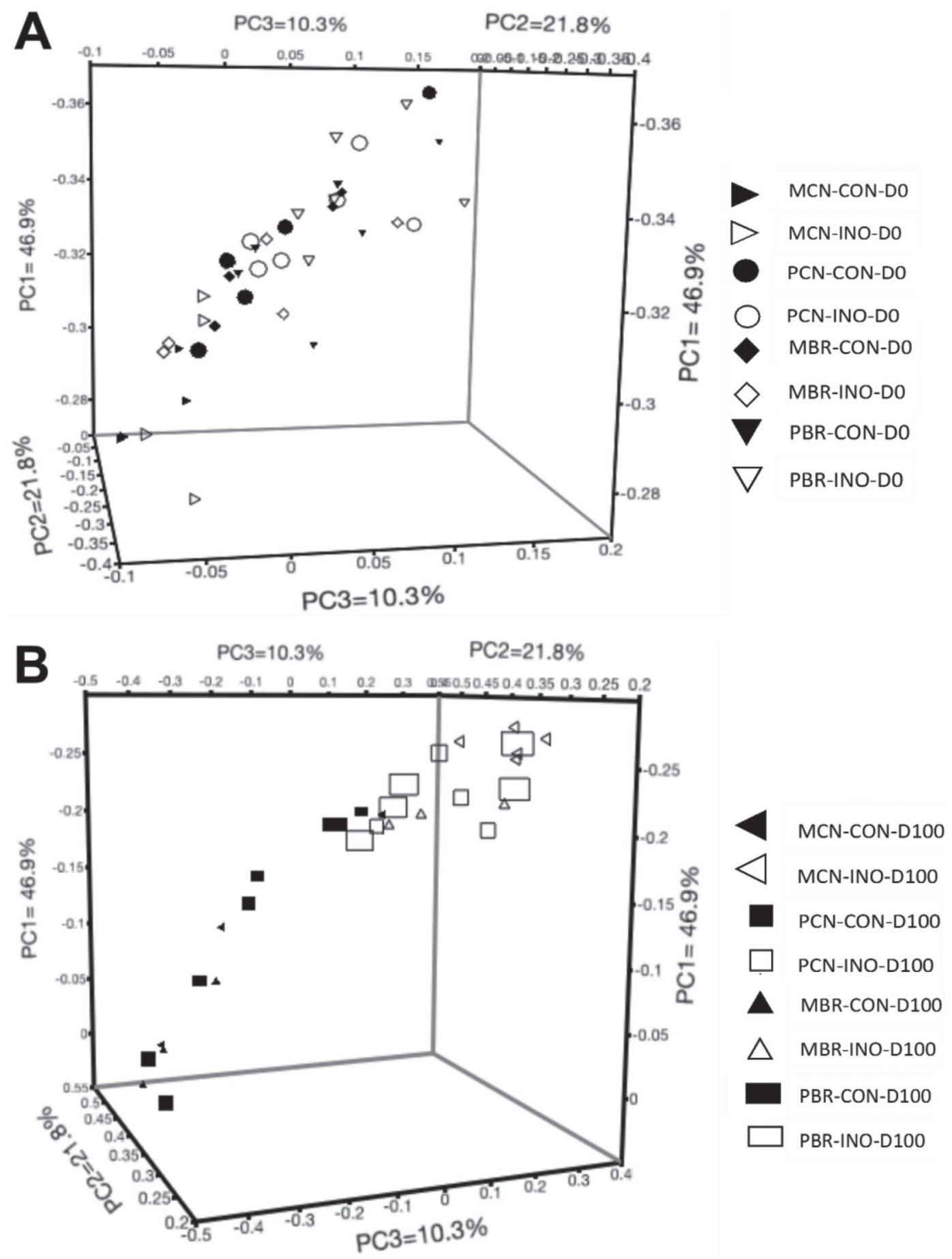

Figure 2. Bray-Curtis principal coordinate analysis plots for fungal operational taxonomic units coming from (A) fresh and (B) ensiled (100 d) chopped whole-crop corn as a function of hybrid and bacterial inoculation. CON = control (water), INO = inoculant. MCN, PCN, MBR, and PBR corn hybrids are TMF2R737, P2089YHR, F2F817, and P1449XR, respectively. Hybrids MCN and MBR are property of Mycogen Seeds (Indianapolis, IN), and PCN and PBR are property of Pioneer Hi-Bred International (Johnston, IA). MBR and PBR are brown midrib hybrids. The inoculant used was Biotal Buchneri 500 (Lallemand Animal Nutrition, Milwaukee, WI) delivering Lactobacillus buchneri 40788 and Pediococcus pentosaceus at 400,000 and 100,000 cfu/g of fresh corn, respectively. 
cereal silages. Furthermore, Li and Nishino (2011) also reported the disappearance of Pichia anomala in wilted Italian ryegrass ensiled for $120 \mathrm{~d}$ due to inoculation with L. buchneri.

The most abundant genera were Meyerozyma for Debaryomycetaceae, Issatchenkia and Pichia for Pichiacea, Candida for incertae sedis Saccharomycetales, Hannaella for incertae sedis Tremellales, and Mucor for Mucoraceae. May et al. (2001) reported the presence of Aspergillus clavatus, Bullera pseudoalba, Candida spp., Mucor racemosus, and Pichia anomala in corn silage treated or not with an inoculant containing Lactobacillus plantarum, Enterococcus faecium, and L. buchneri applied at a rate of $5.7 \mathrm{log} \mathrm{cfu} / \mathrm{g}$ and a second undescribed inoculant. In a corn silage ensiled for 3 mo, May et al. (2001) was only able to observe a fainter band for all the other fungi except for a band that may be Gomphus floccosus (Gomphaceae) for the combination inoculant treatment compared with untreated corn silage. In that study, the undescribed inoculant denaturing gradient gel electrophoresis band pattern (i.e., fungal diversity) was undistinguishable from the untreated silage.

Relationship Between Microbial Taxonomic Profiles and Silage Quality Variables at Silo Opening. The results from the association analysis between microbiota families RA and silage quality at d 100 are presented in Table 9. Only those association with a $P$-value $\leq 0.01$ are reported. The association analysis was conducted separately for CON and INO samples because these are 2 distinct environments and to allow for the evaluation of the associations between microbiota and silage quality without the overriding ef-

Table 8. Relative abundance (\%) of fungal families identified from internal transcribed spacer 1 (ITS-1) region sequences extracted from chopped whole-crop corn as a function of hybrid (HYB) and silage additives (ADV) at d 100,2

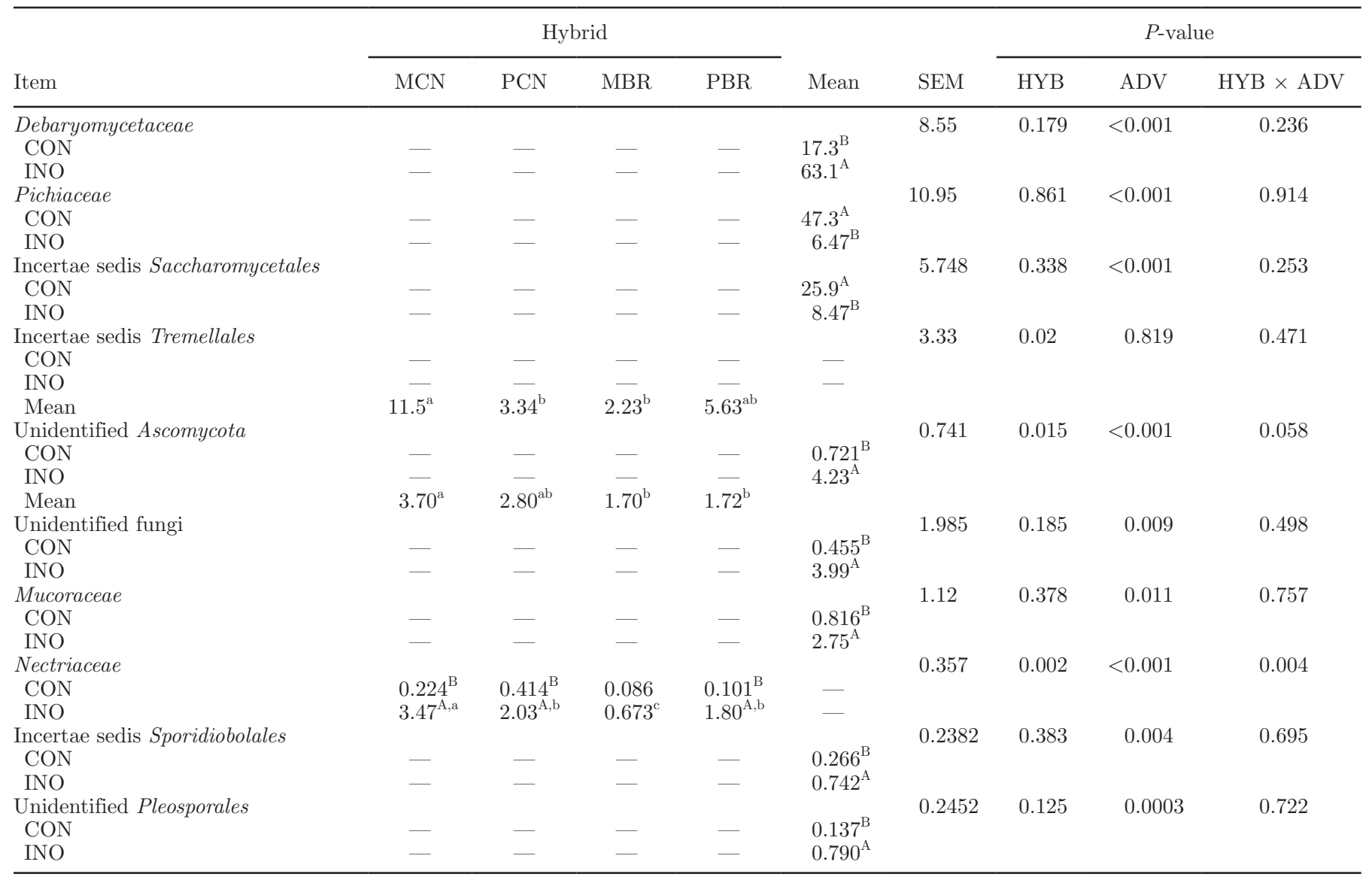

\footnotetext{
${ }_{\mathrm{A}, \mathrm{B}}$ Means with different uppercase superscripts within a column are significantly different $(P \leq 0.05)$.

${ }^{\mathrm{a}-\mathrm{c}}$ Means with different lowercase superscripts within a row are significantly different $(P \leq 0.05)$.

${ }^{1} \mathrm{MCN}, \mathrm{PCN}, \mathrm{MBR}$, and PBR corn hybrids are TMF2R737, P2089YHR, F2F817, and P1449XR, respectively. Hybrids MCN and MBR are property of Mycogen Seeds (Indianapolis, IN), and hybrids PCN and PBR are property of Pioneer Hi-Bred International (Johnston, IA); MBR and PBR are brown midrib hybrids.

${ }^{2} \mathrm{CON}=$ control (water); INO = inoculant (Biotal Buchneri 500; Lallemand Animal Nutrition, Milwaukee, WI) delivering Lactobacillus buchneri 40788 and Pediococcus pentosaceus at 400,000 and 100,000 cfu/g of fresh corn, respectively.
} 
Table 9. Effect of relative abundance (\%) of microbiota families ${ }^{1,2}$ on quality measures of chopped whole corn at d 100

\begin{tabular}{|c|c|c|c|c|c|}
\hline Item & Family and day & \multicolumn{3}{|c|}{ Relative abundance } & $P$-value \\
\hline \multicolumn{6}{|l|}{ CON samples } \\
\hline Aerobic stability, h & Unidentified Ascomycota, $100 \mathrm{~d}$ & $-10.527^{\mathrm{a}}$ & $-8.367^{\mathrm{a}}$ & $17.973^{\mathrm{b}}$ & 0.002 \\
\hline DM recovery, \% & Unidentified Ascomycota, $100 \mathrm{~d}$ & $0.358^{\mathrm{a}}$ & $-2.814^{\mathrm{b}}$ & $1.748^{\mathrm{a}}$ & 0.001 \\
\hline Lactic acid, \% of DM & Alcaligenaceae, $0 \mathrm{~d}$ & $-0.424^{\mathrm{a}}$ & $0.662^{\mathrm{b}}$ & $-0.155^{\mathrm{a}}$ & 0.002 \\
\hline $\mathrm{pH}$ & Incertae sedis Tremellales, $100 \mathrm{~d}$ & $0.044^{\mathrm{a}}$ & $-0.062^{\mathrm{b}}$ & $0.028^{\mathrm{a}}$ & 0.010 \\
\hline WSC, ${ }^{3} \%$ of DM & Sphingobacteriaceae, $0 \mathrm{~d}$ & $0.235^{\mathrm{a}}$ & $-0.378^{\mathrm{b}}$ & $0.096^{\mathrm{a}}$ & 0.000 \\
\hline WSC, $\%$ of DM & Sphingomonadaceae, $0 \mathrm{~d}$ & $0.068^{\mathrm{a}}$ & $0.250^{\mathrm{a}}$ & $-0.287^{\mathrm{b}}$ & 0.005 \\
\hline WSC, $\%$ of DM & Pichiaceae, $100 \mathrm{~d}$ & $-0.424^{\mathrm{a}}$ & $0.223^{\mathrm{b}}$ & $0.116^{\mathrm{b}}$ & 0.009 \\
\hline Yeast, $\log \mathrm{cfu} / \mathrm{g}$ of $\mathrm{FW}^{4}$ & Debaryomycetaceae, $100 \mathrm{~d}$ & $0.759^{\mathrm{a}}$ & $0.091^{\mathrm{a}}$ & $-1.143^{\mathrm{b}}$ & 0.003 \\
\hline Yeast, log cfu/g of FW & Pichiaceae, $100 \mathrm{~d}$ & $-1.143^{\mathrm{a}}$ & $-0.095^{\mathrm{b}}$ & $0.908^{\mathrm{b}}$ & 0.001 \\
\hline Yeast, log cfu/g of FW & Unidentified Ascomycota, $100 \mathrm{~d}$ & $0.908^{\mathrm{a}}$ & $-0.094^{\mathrm{a}}$ & $-1.144^{\mathrm{b}}$ & 0.001 \\
\hline \multicolumn{6}{|c|}{${ }^{\mathrm{a}, \mathrm{b}}$ Coefficients with different superscripts within a row are significantly different $(P \leq 0.05)$. } \\
\hline \multicolumn{6}{|c|}{$\begin{array}{l}{ }^{1} \text { Microbiota relative abundance was classified into } 3 \text { categories as separated by the } 34 \text { th and } 67 \text { th percentiles and tested via least squares analysis } \\
\text { with pairwise contrasts. }\end{array}$} \\
\hline \multicolumn{6}{|c|}{$\begin{array}{l}{ }^{2} \mathrm{CON}=\text { control (water); INO = inoculant (Biotal Buchneri 500; Lallemand Animal Nutrition, Milwaukee, WI) delivering Lactobacillus buchner } \\
40788 \text { and Pediococcus pentosaceus at 400,000 and 100,000 cfu/g of fresh corn, respectively. }\end{array}$} \\
\hline
\end{tabular}

fect of inoculation. We found 14 significant associations for $\mathrm{CON}$ and 3 for INO.

For CON samples, some of the associations showed a linear trend. At high RA of Debaryomycetaceae, unidentified fungi, and unidentified Ascomycota, yeast population counts decreased relative to their medium and low RA $(P<0.003)$. Conversely, yeast counts increased at high RA of Pichiaceae relative to their medium and low RA $(P=0.001)$. Reasons for these associations remain unclear, but we also observed a negative relationship between Debaryomycetaceae and yeast counts and a positive one for Pichiaceae when comparing CON versus INO at $d$ 100. The WSC at silo opening increased at high and medium RA of Pichiaceae relative to its low RA at $\mathrm{d} 100(P=0.009)$. However, WSC decreased at high RA of Sphingomonadaceae relative to its medium and low RA at d $0(P=0.009)$. Higher WSC at d 100 may have sustained a higher Pichiaceae RA, similar to previous reports describing a higher risk of yeast spoilage with higher residual WSC (McDonald et al., 1991). Lactic acid concentration decreased at high RA of Pseudomonadaceae relative to its medium and low RA at d $0(P=0.002)$, and aerobic stability increased at high RA of unidentified Ascomycota relative to its medium and low RA at d $100(P=0.002)$, as this fungus may have limited the growth of other microbes responsible of aerobic spoilage. Associations between other pairs of variables showed different trends, with the medium RA category showing lower values than the other 2 categories (low and high RA) for the following silage variables: ADF and Sphingobacteriaceae at d $0(P$ $=0.004), \mathrm{DM}$ recovery and unidentified Ascomycota at d $100(P=0.001)$, NDF and Sphingobacteriaceae at d 0 $(P=0.003), \mathrm{pH}$ and incertae sedis Tremellales at $\mathrm{d} 100$ $(P=0.010)$, and WSC and Sphingobacteriaceae at d 0 $(P<0.001)$. In the case of Alcaligenaceae, lactic acid increased at its medium RA relative to low and high RA at $\mathrm{d} 0(P=0.002)$. In the case of INO samples, which were much less diverse, we observed that 1,2-propanediol increased at medium and high RA of unidentified fungi relative to low RA at d $100(P=0.005)$.

\section{CONCLUSIONS}

For low-moisture whole-crop corn at d 0, we found higher bacterial and similar fungal phyllosphere diversity for both BMR mutants (MBR and PBR) relative to the conventional hybrids ( $\mathrm{MCN}$ and $\mathrm{PCN}$ ). The most abundant bacterial and fungal families observed at d 0 were Enterobacteriaceae and incertae sedis Tremellales, respectively. Higher RA of Rhizobiaceae, Pseudomonadaceae, Alcaligenaceae, and Sphingomonadaceae was observed for MBR relative to MCN and PCN. In the case of fungi, we did not observe a clear pattern 
for hybrid effects across several fungal families. The responses observed for $\mathrm{MBR}$ may be related to its lower maturity compared with the other hybrids, reflected in the lower DM and OM and higher CP, WSC, NDF, and $\mathrm{NH}_{3}-\mathrm{N}$. At silo opening (d 100), we observed no effects of INO on DM recovery; however, we found hybrid effects with lower values for MBR and PBR (BMR hybrids) compared with MCN. Aerobic stability was extended for at least a factor of $5 \times$ for all INO-treated hybrids except for MBR. Furthermore, INO reduced bacterial and increased fungal diversity across all hybrids. The predominant bacterial and fungal families at silo opening were Lactobacillaceae and Debaryomycetaceae, respectively. We observed that INO increased the RA of Lactobacillaceae across all hybrids, and to larger extent for MBR, and decreased Enterobacteriaceae, Streptococcaceae, Xanthomonadaceae, Aeromonadaceae, and Brucellaceae compared with CON. For fungi, INO increased the RA of Debaryomycetaceae, unidentified Ascomycota, unidentified fungi, Mucoraceae, incertae sedis Sporidiobolales, and unidentified Pleosporales and decreased the RA of Pichiaceae and incertae sedis Saccharomycetales compared with CON. The bacterial and fungal community structure changed to a distinct and consistent community when INO was applied relative to CON. In conclusion, at the low moisture concentrations evaluated in this study, the INO tested improved whole-crop corn silage quality because of a shift in the bacterial and fungal community composition during ensiling that favored aerobic stability for all hybrids except MBR and a similar DM recovery relative to CON.

\section{ACKNOWLEDGMENTS}

Funding was provided by the North Carolina Dairy Producers Association (Raleigh, NC), and the inoculant was donated by Lallemand Animal Nutrition (Milwaukee, WI). We acknowledge the outstanding work of Y. Zhao [short-term scholar at North Carolina State University (NCSU) from China Agricultural University, Beijing]; M. A. Balseca-Paredes, M. Dalman, and A. Heitman (NCSU); M. Massel (research technician, NCSU); D. Reyes (University of Maine, Orono); Carrie Brinton (Official Variety Testing Program at NCSU); and the staff from the North Carolina Department of Agriculture Piedmont Research Station (Salisbury, $\mathrm{NC})$.

\section{REFERENCES}

Allen, M. S., J. G. Coors, and G. W. Roth. 2003. Corn silage. Pages 547-608 in Silage Science and Technology. American Society of Agronomy, Crop Science Society, Madison, WI.

AOAC International. 2000. Official Methods of Analysis. 17th ed. AOAC Int., Arlington, VA.
Arriola, K. G., S. C. Kim, and A. T. Adesogan. 2011. Effect of applying inoculants with heterolactic or homolactic and heterolactic bacteria on the fermentation and quality of corn silage. J. Dairy Sci. 94:1511-1516.

Arriola, K. G., O. C. M. Queiroz, J. J. Romero, D. Casper, E. Muniz, J. Hamie, and A. T. Adesogan. 2015. Effect of microbial inoculants on the quality and aerobic stability of bermudagrass round-bale haylage. J. Dairy Sci. 98:478-485.

Beck, T. 1978. The microbiology of silage fermentation. Pages 61-116 in Fermentation of Silage-A Review. M. E. McCullough, ed. National Feed Ingredients Association, Des Moines, IA.

Bokulich, N. A., C. M. L. Joseph, G. Allen, A. Benson, and D. A. Mills. 2012. Next-generation sequencing reveals significant bacterial diversity of botrytized wine. PLoS One 7:e36357.

Bokulich, N. A., and D. A. Mills. 2013. Improved selection of internal transcribed spacer-specific primers enables quantitative, ultrahigh-throughput profiling of fungal communities. Appl. Environ. Microbiol. 79:2519-2526.

Cabo, M. L., A. F. Braber, and P. M. F. J. Koenraad. 2002. Apparent antifungal activity of several lactic acid bacteria against penicillium discolor is due to acetic acid in the medium. J. Food Prot. 65:1309-1316.

Caporaso, J. G., C. L. Lauber, W. A. Walters, D. Berg-Lyons, C. A. Lozupone, P. J. Turnbaugh, N. Fierer, and R. Knight. 2011. Global patterns of $16 \mathrm{~S}$ rRNA diversity at a depth of millions of sequences per sample. Proc. Natl. Acad. Sci. USA 108(Suppl. 1):4516-4522.

Cherney, J., and D. Cherney. 2003. Assessing silage quality. Pages 141-198 in Silage Science and Technology. D. Buxton, R. E. Muck, and J. Harrison, ed. American Society of Agronomy, Crop Science Society of America, and Soil Science Society of America, Madison, WI

Cole, J. R., B. Chai, R. J. Farris, Q. Wang, and A. S. Kulam-SyedMohideen. 2007. The ribosomal database project (RDP-II): Introducing myRDP space and quality controlled public data. Nucleic Acids Res. 35:D169-D172.

Cole, J. R., Q. Wang, E. Cardenas, J. Fish, and B. Chai. 2009. The Ribosomal Database Project: Improved alignments and new tools for rRNA analysis. Nucleic Acids Res. 37:D141-D145.

Comino, L., E. Tabacco, F. Righi, A. Revello-Chion, A. Quarantelli, and G. Borreani. 2014. Effects of an inoculant containing a Lactobacillus buchneri that produces ferulate-esterase on fermentation products, aerobic stability, and fibre digestibility of maize silage harvested at different stages of maturity. Anim. Feed Sci. Technol. 198:94-106.

Contreras-Govea, F. E., R. E. Muck, D. R. Mertens, and P. J. Weimer. 2011. Microbial inoculant effects on silage and in vitro ruminal fermentation, and microbial biomass estimation for alfalfa, BMR corn, and corn silages. Anim. Feed Sci. Technol. 163:2-10.

Corte, L., R. di Cagno, M. Groenewald, L. Roscini, C. Colabella, M. Gobbetti, and G. Cardinali. 2015. Phenotypic and molecular diversity of Meyerozyma guilliermondii strains isolated from food and other environmental niches, hints for an incipient speciation. Food Microbiol. 48:206-215.

Der Bedrosian, M. C., K. E. Nestor Jr., and L. Kung Jr.. 2012. The effects of hybrid, maturity, and length of storage on the composition and nutritive value of corn silage. J. Dairy Sci. 95:5115-5126.

Desjardins, A. E. 2003. Gibberella from A (venaceae) to Z (eae). Annu. Rev. Phytopathol. 41:177-198.

Driehuis, F., S. J. W. H. Oude Elferink, and P. G. Van Wikselaar. 2001. Fermentation characteristics and aerobic stability of grass silage inoculated with Lactobacillus buchneri, with or without homofermentative lactic acid bacteria. Grass Forage Sci. 56:330-343.

DuBois, M., K. A. Gilles, J. K. Hamilton, P. A. Rebers, and F. Smith. 1956. Colorimetric method for determination of sugars and related substances. Anal. Chem. 28:350-356.

Eikmeyer, F. G., P. Köfinger, A. Poschenel, S. Jünemann, M. Zakrzewski, S. Heinl, E. Mayrhuber, R. Grabherr, A. Pühler, H. Schwab and A. Schlüter. 2013. Metagenome analyses reveal the influence of the inoculant Lactobacillus buchneri CD034 on the microbial community involved in grass ensiling. J. Biotechnol. 167:334-343. 
FCC. 2015. Food Chemicals Codex. 9th ed. National Academy Press, Washington, DC.

Fox, J., and S. Weisberg. 2011. An $\{\mathrm{R}\}$ Companion to Applied Regression. 2nd ed. Sage, Thousand Oaks, CA.

Galicia, L., E. Nurit, A. Rosales, and N. Palacios-Rojas. 2008. Maize Nutrition Quality and Plant Tissue Analysis Laboratory. International Maize and Wheat Improvement Center, Mexico, D.F., Mexico.

Goodwin, S. B., L. D. Dunkle, and V. L. Zismann. 2001. Phylogenetic analysis of Cercospora and Mycosphaerella based on the internal transcribed spacer region of ribosomal DNA. Phytopathology 91:648-658.

Gutiérrez-Rodríguez, E., A. Gundersen, A. O. Sbodio, and T. V. Suslow. 2012. Variable agronomic practices, cultivar, strain source and initial contamination dose differentially affect survival of Escherichia coli on spinach. J. Appl. Microbiol. 112:109-118.

Hall, M. B. 2000. Neutral detergent-solubles carbohydrates nutritional relevance and analysis: A laboratory manual. Vol. Bull. 339. University of Florida IFAS Extension.

Hardy, D. H., M. R. Tucker, and C. E. Stokes. 2014. Crop fertilization based on North Carolina soil tests. Circular no. 1. North Carolina Department of Agriculture and Consumer Services, Agronomic Division, Raleigh, NC.

Heron, S. J., J. Wilkinson, and C. M. Duffus. 1993. Enterobacteria associated with grass and silages. J. Appl. Bacteriol. 75:13-17.

Hristov, A. N., and T. A. McAllister. 2002. Effect of inoculants on whole-crop barley silage fermentation and dry matter disappearance in situ. J. Anim. Sci. 80:510-516.

Hu, W., R. J. Schmidt, E. E. McDonell, C. M. Klingerman, and L. Kung Jr.. 2009. The effect of Lactobacillus buchneri 40788 or Lactobacillus plantarum MTD-1 on the fermentation and aerobic stability of corn silages ensiled at two dry matter contents. J. Dairy Sci. 92:3907-3914.

Huber, J. T., and M. Soejono. 1976. Organic acid treatment of high dry matter corn silage fed lactating dairy cows. J. Dairy Sci. 59:2063-2070.

Huisden, C. M., A. T. Adesogan, S. C. Kim, and T. Ososanya. 2009. Effect of applying molasses or inoculants containing homofermentative or heterofermentative bacteria at two rates on the fermentation and aerobic stability of corn silage. J. Dairy Sci. 92:690-697.

Kado, C. I. 2006. Erwinia and related genera. Pages 443-450 in The Prokaryotes: Volume 6: Proteobacteria: Gamma Subclass. M. Dworkin, S. Falkow, E. Rosenberg, K.-H. Schleifer, and E. Stackebrandt, ed. Springer, New York, NY.

Kleinschmit, D. H., and L. Kung Jr. 2006a. The effects of Lactobacillus buchneri 40788 and Pediococcus pentosaceus R1094 on the fermentation of corn silage. J. Dairy Sci. 89:3999-4004.

Kleinschmit, D. H., and L. Kung Jr. 2006b. A meta-analysis of the effects of Lactobacillus buchneri on the fermentation and aerobic stability of corn and grass and small-grain silages. J. Dairy Sci. 89:4005-4013.

Kraut-Cohen, J., V. Tripathi, Y. Chen, J. Gatica, V. Volchinski, S. Sela, Z. Weinberg, and E. Cytryn. 2016. Temporal and spatial assessment of microbial communities in commercial silages from bunker silos. Appl. Microbiol. Biotechnol. 100:6827-6835.

Krooneman, J., F. Faber, A. C. Alderkamp, S. J. H. W. O. Elferink, F. Driehuis, I. Cleenwerck, J. Swings, J. C. Gottschal, and M. Vancanneyt. 2002. Lactobacillus diolivorans sp. nov., a 1,2-propanediol-degrading bacterium isolated from aerobically stable maize silage. Int. J. Syst. Evol. Microbiol. 52:639-646.

Kung, L. Jr., J. M. Lim, D. J. Hudson, J. M. Smith, and R. D. Joerger. 2015. Chemical composition and nutritive value of corn silage harvested in the northeastern United States after Tropical Storm Irene. J. Dairy Sci. 98:2055-2062.

Landell, M. F., L. R. Brandão, A. C. Barbosa, J. P. Ramos, S. V. B. Safar, F. C. O. Gomes, F. M. P. Sousa, P. B. Morais, L. Broetto, O. Leoncini, J. R. Ribeiro, B. Fungsin, M. Takashima, T. Nakase, C.-F. Lee, M. H. Vainstein, J. W. Fell, G. Scorzetti, H. S. Vishniac, C. A. Rosa, and P. Valente. 2014. Hannaella pagnoccae sp. nov., a tremellaceous yeast species isolated from plants and soil. Int. J. Syst. Evol. Microbiol. 64:1970-1977.
Lenth, R. V. 2016. Least-squares means: The R package lsmeans. J. Stat. Softw. 69:1-33.

Li, Y., and N. Nishino. 2011. Bacterial and fungal communities of wilted Italian ryegrass silage inoculated with and without Lactobacillus rhamnosus or Lactobacillus buchneri. Lett. Appl. Microbiol. $52: 314-321$.

Lozupone, C., and R. Knight. 2005. UniFrac: A new phylogenetic method for comparing microbial communities. Appl. Environ. Microbiol. 71:8228-8235.

May, L. A., B. Smiley, and M. G. Schmidt. 2001. Comparative denaturing gradient gel electrophoresis analysis of fungal communities associated with whole plant corn silage. Can. J. Microbiol. 47:829-841.

McDonald, P., A. R. Henderson, and S. J. E. Heron. 1991. The Biochemistry of Silage. Chalcombe, Marlow, UK.

McGarvey, J. A., R. B. Franco, J. D. Palumbo, R. Hnasko, L. Stanker, and F. M. Mitloehner. 2013. Bacterial population dynamics during the ensiling of Medicago sativa (alfalfa) and subsequent exposure to air. J. Appl. Microbiol. 114:1661-1670.

McKenzie, H., and H. Wallace. 1954. The Kjeldahl determination of Nitrogen: A critical study of digestion conditions-Temperature, catalyst, and oxidizing agent. Aust. J. Chem. 7:55-70.

Moon, N. J. 1983. Inhibition of the growth of acid tolerant yeasts by acetate, lactate and propionate and their synergistic mixtures. J. Appl. Bacteriol. 55:453-460.

Muck, R. 2013. Recent advances in silage microbiology. 2013. Agric. Food Sci. 22:3-15.

Muck, R., and L. Kung Jr. 2007. Silage production. Pages 617-633 in Forages: The Science of Grassland Agriculture. Vol. 2. Blackwell, Ames, IA

Mustafa, A. F., P. Seguin, O. Marois-Mainguy, and D. R. Ouellet. 2005. Ensiling characteristics, nutrient composition, and in situ ruminal and whole tract degradability of brown midrib and leafy corn silage. Arch. Anim. Nutr. 59:353-363.

Nakase, T. 2000. Expanding world of ballistosporous yeasts: Distribution in the phyllosphere, systematics and phylogeny. J. Gen. Appl. Microbiol. 46:189-216.

Ni, K., T. T. Minh, T. T. M. Tu, T. Tsuruta, H. Pang, and N. Nishino. 2017. Comparative microbiota assessment of wilted Italian ryegrass, whole crop corn, and wilted alfalfa silage using denaturing gradient gel electrophoresis and next-generation sequencing. Appl. Microbiol. Biotechnol. 101:1385-1394.

Noel, R. J., and L. G. Hambleton. 1976. Collaborative study of a semiautomated method for determination of crude protein in animal feeds. J. Assoc. Off. Anal. Chem. 59:134-140.

Oude Elferink, S. J. W. H., J. Krooneman, J. C. Gottschal, S. F. Spoelstra, F. Faber, and F. Driehuis. 2001. Anaerobic conversion of lactic acid to acetic acid and 1,2-propanediol by Lactobacillus buchneri. Appl. Environ. Microbiol. 67:125-132.

Pahlow, G., R. E. Muck, F. Driehuis, S. J. O. Elferink, and S. F. Spoelstra. 2003. Microbiology of ensiling. Pages 31-94 in Silage Science and Technology. D. Buxton, R. E. Muck, and J. Harrison, ed. American Society of Agronomy, Crop Science Society of America, and Soil Science Society of America, Madison, WI.

Queiroz, O. C. M., K. G. Arriola, J. L. P. Daniel, and A. T. Adesogan. 2013. Effects of 8 chemical and bacterial additives on the quality of corn silage. J. Dairy Sci. 96:5836-5843.

Queiroz, O. C. M., S. C. Kim, and A. T. Adesogan. 2012. Effect of treatment with a mixture of bacteria and fibrolytic enzymes on the quality and safety of corn silage infested with different levels of rust. J. Dairy Sci. 95:5285-5291.

Reich, L. J., and L. Kung Jr.. 2010. Effects of combining Lactobacillus buchneri 40788 with various lactic acid bacteria on the fermentation and aerobic stability of corn silage. Anim. Feed Sci. Technol. 159:105-109

Romero, J. J., J. W. Park, Y. Zhao, Y. H. Joo, M. A. Balseca-Paredes, E. Gutierrez-Rodriguez, and M. S. Castillo. 2017a. Microbial community structure of conventional and brown midrib corns ensiled at low dry matter concentrations with and without a combo inoculant. J. Dairy Sci. 100(Suppl. 2):317. (Abstr.). 
Romero, J. J., Y. Zhao, M. A. Balseca-Paredes, F. Tiezzi, E. Gutierrez-Rodriguez, and M. S. Castillo. 2017b. Laboratory silo type and inoculation effects on nutritional composition, fermentation, and bacterial and fungal communities of oat silage. J. Dairy Sci. 100:1812-1828.

Rosenzweig, C., A. Iglesias, X. Yang, P. R. Epstein, and E. Chivian. 2001. Climate change and extreme weather events; Implications for food production, plant diseases, and pests. Glob. Change Hum. Health 2:90-104.

Ruppel, K. A. 1992. Effects of bunker silo management on haycrop nutrient preservation. MS. Thesis. Cornell University, Ithaca, NY.

Sani, N. A., and O. A. Odeyemi. 2015. Occurrence and prevalence of Cronobacter spp. in plant and animal derived food sources: A systematic review and meta-analysis. Springerplus 4:545.

Schmidt, R. J., and L. Kung Jr.. 2010. The effects of Lactobacillus buchneri with or without a homolactic bacterium on the fermentation and aerobic stability of corn silages made at different locations. J. Dairy Sci. 93:1616-1624.

Siegfried, V. R., H. Ruckemmann, and G. Stumpf. 1984. Method for the determination of organic acids in silage by high performance liquid chromatography. Landwirtsch. Forsch. 37:298-304.

Thomas, E. D., P. Mandebvu, C. S. Ballard, C. J. Sniffen, M. P Carter, and J. Beck. 2001. Comparison of corn silage hybrids for yield, nutrient composition, in vitro digestibility, and milk yield by dairy cows. J. Dairy Sci. 84:2217-2226.

US Environmental Protection Agency. 1993. Methods for the determination of inorganic substances in environmental samples. USEPA 600/R-93/100. Method 353.2. USEPA, Washington, DC.

Van Amburgh, M. E., E. A. Collao-Saenz, R. J. Higgs, D. A. Ross, E. B. Recktenwald, E. Raffrenato, L. E. Chase, T. R. Overton, J. K. Mills, and A. Foskolos. 2015. The Cornell Net Carbohydrate and Protein System: Updates to the model and evaluation of version 6.5. J. Dairy Sci. 98:6361-6380.

Van Soest, P. J., J. B. Robertson, and B. A. Lewis. 1991. Methods for dietary fiber, neutral detergent fiber and non-starch polysaccharides in relation to animal nutrition. J. Dairy Sci. 74:3583-3597.

Weiss, W. P. 2003. Harvesting and Storing Dry Corn Silage. Department of Animal Sciences, The Ohio State University, Columbus.

Wilkinson, J. M., and D. R. Davies. 2013. The aerobic stability of silage: Key findings and recent developments. Grass Forage Sci. 68:1-19.

Zahiroddini, H., J. Baah, and T. A. McAllister. 2006. Effects of microbial inoculants on the fermentation, nutrient retention, and aerobic stability of barley silage. Asian-australias. J. Anim. Sci. 19:1429-1436. 